\title{
Polyunsaturated fatty acid-derived lipid mediators and T cell function
}

\author{
Anna Nicolaou ${ }^{1}$, Claudio Mauro ${ }^{2}$, Paula Urquhart ${ }^{1}$ and Federica Marelli-Berg ${ }^{2}$ \\ ${ }^{1}$ Manchester Pharmacy School, Faculty of Medical and Human Sciences, The University of Manchester, Manchester, UK \\ ${ }^{2}$ Centre for Biochemical Pharmacology, William Harvey Research Institute, Queen Mary University of London, London, UK
}

\section{Edited by:}

Karsten Sauer, The Scripps Research

Institute, USA

\section{Reviewed by:}

John J. Miles, Queensland Institute of Medical Research, Australia

Sid P. Kerkar, National Cancer

Institute, USA

*Correspondence:

Anna Nicolaou, Manchester

Pharmacy School, Faculty of Medical and Human Sciences, The University of Manchester, Stopford Building, Oxford Road, Manchester M13 9PT,

UK

e-mail:anna.nicolaou@

manchester.ac.uk
Fatty acids are involved in T cell biology both as nutrients important for energy production as well as signaling molecules. In particular, polyunsaturated fatty acids are known to exhibit a range of immunomodulatory properties that progress through $T$ cell mediated events, although the molecular mechanisms of these actions have not yet been fully elucidated. Some of these immune activities are linked to polyunsaturated fatty acid-induced alteration of the composition of cellular membranes and the consequent changes in signaling pathways linked to membrane raft-associated proteins. However, significant aspects of the polyunsaturated fatty acid bioactivities are mediated through their transformation to specific lipid mediators, products of cyclooxygenase, lipoxygenase, or cytochrome P450 enzymatic reactions. Resulting bioactive metabolites including prostaglandins, leukotrienes, and endocannabinoids are produced by and/or act upon T leukocytes through cell surface receptors and have been shown to alter $\mathrm{T}$ cell activation and differentiation, proliferation, cytokine production, motility, and homing events. Detailed appreciation of the mode of action of these lipids presents opportunities for the design and development of therapeutic strategies aimed at regulating $T$ cell function.

Keywords: $T$ cells, polyunsaturated fatty acids, eicosanoids, prostaglandins, leukotrienes, cyclooxygenase, lipoxygenase, endocannabinoids

\section{INTRODUCTION}

The regulation of energy metabolism is crucial to T cell-mediated immunity including activation, proliferation, and differentiation (1). Following recognition of antigen in the lymph nodes, naïve T lymphocytes undergo massive clonal expansion and differentiation, followed by a contraction or death phase, and the establishment and maintenance of immunological memory $(2,3)$. Before undergoing division, $\mathrm{T}$ cells activate biosynthetic pathways for the production of proteins, nucleic acids, lipids, carbohydrates, and other "building blocks" necessary for the generation of new cells. Following this stage, the metabolic machinery of $\mathrm{T}$ cells is reprogramed, switching from the $\beta$-oxidation of fatty acids in naive $\mathrm{T}$ cells to the glycolytic pathways in activated $\mathrm{T}$ cells (4-6).

Downstream of T cell receptor (TCR) signaling, phosphatidylinositol 3'-kinase (PI3K) leads to the activation of the serinethreonine kinase AKT, which promotes glucose metabolism by stimulating the localization of the glucose transporter Glut 1 to the plasma membrane, and the activity of hexokinase and phosphofructokinase, two rate-limiting enzymes of the glycolytic pathway. Increased glycolytic flux enables activated T cells to generate ATP and, at the same time, efficiently utilize carbon sources in the form of amino acids and lipids for the biosynthesis of proteins and membranes necessary for the expansion phase that characterizes the immune response (7-11). AKT also controls the activation state of mammalian target of rapamycin (mTOR), a sensor of nutritional and energetic status in cells that promotes protein synthesis.
$\mathrm{T}$ cell activation also initiates distinct transcriptional programs, which determine their differentiation into functional subsets depending on the context [cytokines, prostaglandins (PG), and other extracellular signals] in which they were activated (12-14). These subsets define the characteristics of the immune response. Whereas $\mathrm{CD} 8+\mathrm{T}$ cells differentiate into cytotoxic $\mathrm{T}$ lymphocytes that kill infected host cells, CD4+ Tlymphocytes differentiate into either the Th1, Th2, or Th17 subset of helper T cells (effector T cells) that mediate appropriate immune responses or into induced regulatory $\mathrm{T}$ cells (iTreg cells) that suppress uncontrolled immune responses (12). There is evidence that the cytokine milieu in which $\mathrm{T}$ cells differentiate can influence their metabolic programing. A comparison of activated $\mathrm{T}$ cells responding to related cytokines IL-2 and IL-15 illustrates the differential regulation of T lymphocyte metabolism by distinct cytokine environments: IL-2 promotes elevated glucose metabolism and glycolysis, while IL-15 does not maintain this metabolic state and T cells responding to IL-15 are smaller with reduced nutrient uptake and glycolysis $(15,16)$.

After clearance of the infection, most clonally expanded and differentiated $\mathrm{T}$ cells undergo apoptosis (contraction phase). The surviving antigen-specific $\mathrm{T}$ cells (memory $\mathrm{T}$ cells) are responsible for enhanced immunity after re-exposure to the same pathogen. Of these various $\mathrm{T}$ cell subsets, the iTreg cells and memory $\mathrm{T}$ cells rely on lipid oxidation as a major source of energy, whereas cytotoxic $\mathrm{T}$ lymphocytes and effector $\mathrm{T}$ cells are characterized by high glycolytic activity (17-19).

Further to oxidation for energy production, fatty acids are involved in many other aspects of $\mathrm{T}$ cell biology. In particular, 
omega-3 polyunsaturated fatty acids ( $n$-3 PUFA) are recognized as modulators of inflammation and immunity mediating their pleiotropic activity through regulation of gene expression, influencing signaling cascades, and altering the composition of the cellular membranes $(20,21)$. The latter has implications for the structure and function of the membrane, as well as a direct impact on the production of $n-6$ and $n-3$ PUFA-derived bioactive lipids including PG, leukotrienes (LT), resolvins (Rv), protectins (PD), endocannabinoids, and related congeners.

Although the immunomodulatory properties of PUFA have been known for many years, the molecular mechanisms underlying these properties are not fully understood. It has been shown that $n-3$ PUFA suppress antigen presentation, $\mathrm{T}$ cell activation and proliferation, and lower the expression of signature cytokines (2127). Disappointingly, early studies using daily supplementation with foods rich in $n$-3 PUFA failed to show significant improvement in organ transplantation rejection $(28,29)$. However, recent reports indicate that administration of purified eicosapentaenoic acid (EPA; 20:5n-3) induces the differentiation of regulatory $\mathrm{T}$ cells through upregulation of peroxisome proliferator-activated receptor $\gamma(\operatorname{PPAR} \gamma)$, a ligand-activated nuclear receptor that regulates lipid and glucose metabolism, leading to increased allograft survival $(30,31)$.

Following this direction, studies have explored the effect of cellular incorporation of the main n-3 PUFA, EPA, and docosahexaenoic acid (DHA; 22:6n-3). These fatty acids can alter the composition and molecular organization of membrane rafts with a consequent impact on the activity of raft-associated signaling proteins and related events. Examples include recruitment and activation of PLC $\gamma$ and F-actin, impairing mitochondrial translocation necessary to maintain $\mathrm{Ca}^{+}$signaling for NFKB and AP-1 activation and IL-2 secretion, and suppression of phosphatidylinositoldependent actin remodeling, all linked to reduced CT4 $+\mathrm{T}$ cell activation [recently reviewed in Ref. (20)]. Importantly, many of the PUFA mediated activities are conveyed through their metabolites that tend to be produced and metabolized upon request, can act near the site of their synthesis or transported via circulation and in this way mediate systemic effects (autacoids). These families of potent mediators are intimately involved in inflammation and immunity, with pro- and/or anti-inflammatory, proliferative, and chemoattractive activities (21).

Overall, these new findings suggest that a better understanding of the molecular mechanism of action of PUFA may lead to the development of effective therapeutics. In this article, we will overview the current knowledge of the function and impact of eicosanoids and related metabolites, as well as that of endocannabinoids and their congeners on $\mathrm{T}$ cell function, and examine potential applications in biomedical research.

\section{PUFA-DERIVED LIPID MEDIATORS: BIOSYNTHESIS AND METABOLISM}

The cellular membrane serves as a pool of PUFA available for further metabolism to various bioactive lipids. These potent autacoids act as local hormones and are produced upon request following the activation of signaling pathways or effect of environmental and other stimuli. The arachidonic acid (AA; C20:4n-3)-derived eicosanoids are some of the best known and studied bioactive lipids. The term "eicosanoids" is used to describe the bioactive derivatives of three fatty acids with 20-carbon acyl chains, namely: AA, EPA, and dihomo-gamma linolenic (DGLA; 20:3n-6). These metabolites, although mostly linked to inflammation, are also involved in cell migration, proliferation, chemotaxis, and immune reactions (32-34). Eicosanoids and related mediators derive from the activities of cyclooxygenases (COX), lipoxygenases (LOX), and cytochrome P450 (CYP) epoxygenases and mono-oxygenases (Figures 1 and 2) [reviewed in Ref. (35)]. The term "endocannabinoids" refers to endogenous lipids ligands of the cannabinoid receptors $\mathrm{CB} 1$ and $\mathrm{CB} 2$. These are also derivatives of $\mathrm{AA}$, while other PUFA ethanolamides are now recognized as members of this family (36). Although endocannabinoids can be metabolized by COX and LOX, their precursor phospholipids and metabolism are different to eicosanoids (Figure 3).

\section{CYCLOOXYGENASE-MEDIATED FORMATION OF PROSTANOIDS}

The eicosanoid cascade starts with the activation of phospholipases (PL), predominantly PLA 2 but also PLD and diacylglycerol (DAG) lipase that release AA and other PUFA from the cellular membrane (35). The family of PLA 2 comprises a large number of enzymes with distinct characteristics in terms of their activation, cellular localization, and substrate specificity (37). There is evidence for the presence of various $\mathrm{PLA}_{2}$ isoforms in primary $\mathrm{T}$ cells and the Jurkat $\mathrm{T}$ cell line, including $\mathrm{CPLA}_{2}, \mathrm{sPLA}_{2}$, and $\mathrm{iPLA}_{2}$ (38-42). Inducible isoforms of PLC and DAG lipase have also been identified in tumor and peripheral T lymphocytes $(42,43)$.

Free AA is then metabolized via the constitutive and inducible COX isoforms (COX-1 and -2 , respectively) to the unstable endoperoxide $\mathrm{PGH}_{2}$ that is then transformed to $\mathrm{PG}$, thromboxanes (TX), and prostacyclin $\left(\mathrm{PGI}_{2}\right)$ via tissue specific terminal prostaglandin synthases (Figure 1); these COX-derived mediators belong to the family of eicosanoids and are collectively known as prostanoids. Apart from AA, prostanoids are formed from the other two 20-carbon containing PUFA, DGLA, and EPA, with the resulting metabolites having different activities and being considered less-inflammatory than the AA-derived ones $(35,44)$.

The exact profile of prostanoids is determined by the prevalence of specific synthases in the cell type or tissue of interest. $\mathrm{PGE}_{2}$ is produced by prostaglandin $\mathrm{E}$ synthase (PGES) that is found as membrane bound (mPGES-1 and -2) or cytosolic (cPGES). mPGES-1 is an inducible isoform and is frequently found co-expressed with COX-2 $(45,46) . \mathrm{PGD}_{2}$ is produced by the hematopoietic-type (H-PGDS) or the lipocalin-type (LPGDS) synthases (47), while further non-enzymatic hydrolysis of $\mathrm{PGD}_{2}$ gives rise to the anti-inflammatory cyclopentanone PGs $\mathrm{PGJ}_{2}$ and $15 \mathrm{~d}-\mathrm{PGJ}_{2}(48,49) . \mathrm{PGF}_{2 \alpha}$ is produced either directly from $\mathrm{PGH}_{2}$ via the prostaglandin $\mathrm{F}$ synthase (PGFS) or through further metabolism of $\mathrm{PGE}_{2}$ and $\mathrm{PGD}_{2}$ by PGE 9-ketoreductase and PGD 11-ketoreductase, respectively (50). Prostacyclin $\left(\mathrm{PGI}_{2}\right)$ is produced via the prostacyclin synthase (PGIS) and is usually detected as its stable but inactive metabolite 6-keto-PGF ${ }_{1 \alpha}$ (51). Finally, thromboxane synthase (TXS) converts $\mathrm{PGH}_{2}$ to $\mathrm{TXA}_{2}$, an unstable prostanoid that is quickly hydrolyzed to the stable but inert metabolite $\mathrm{TXB}_{2}$ (51). The bioactivity of prostanoids is mediated through $\mathrm{G}$ protein-coupled receptors for $\mathrm{PGE}_{2}, \mathrm{PGD}_{2}$, $\mathrm{PGF}_{2 \alpha}, \mathrm{PGI}_{2}$, and $\mathrm{TXA}_{2}$, designated EP, DP, FP, IP, and TP, 


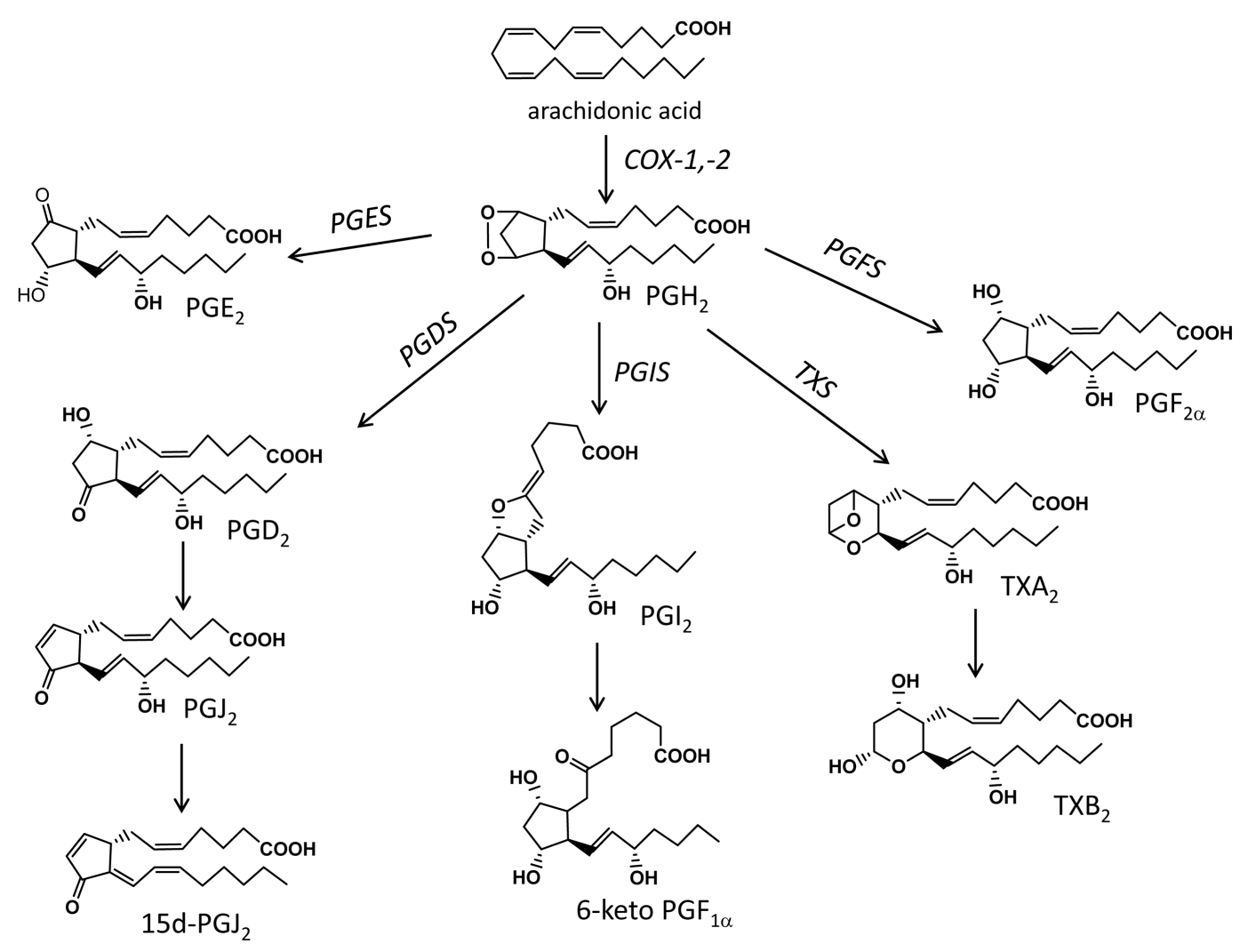

FIGURE 1 | Schematic representation of the main biochemical pathways that mediate the production of prostanoids. COX, cyclooxygenase; PGES, prostaglandin E synthase; PGDS, prostaglandin D synthase; PGFS, prostaglandin F synthase; PGIS, prostacyclin synthase; TXS, thromboxane synthase.

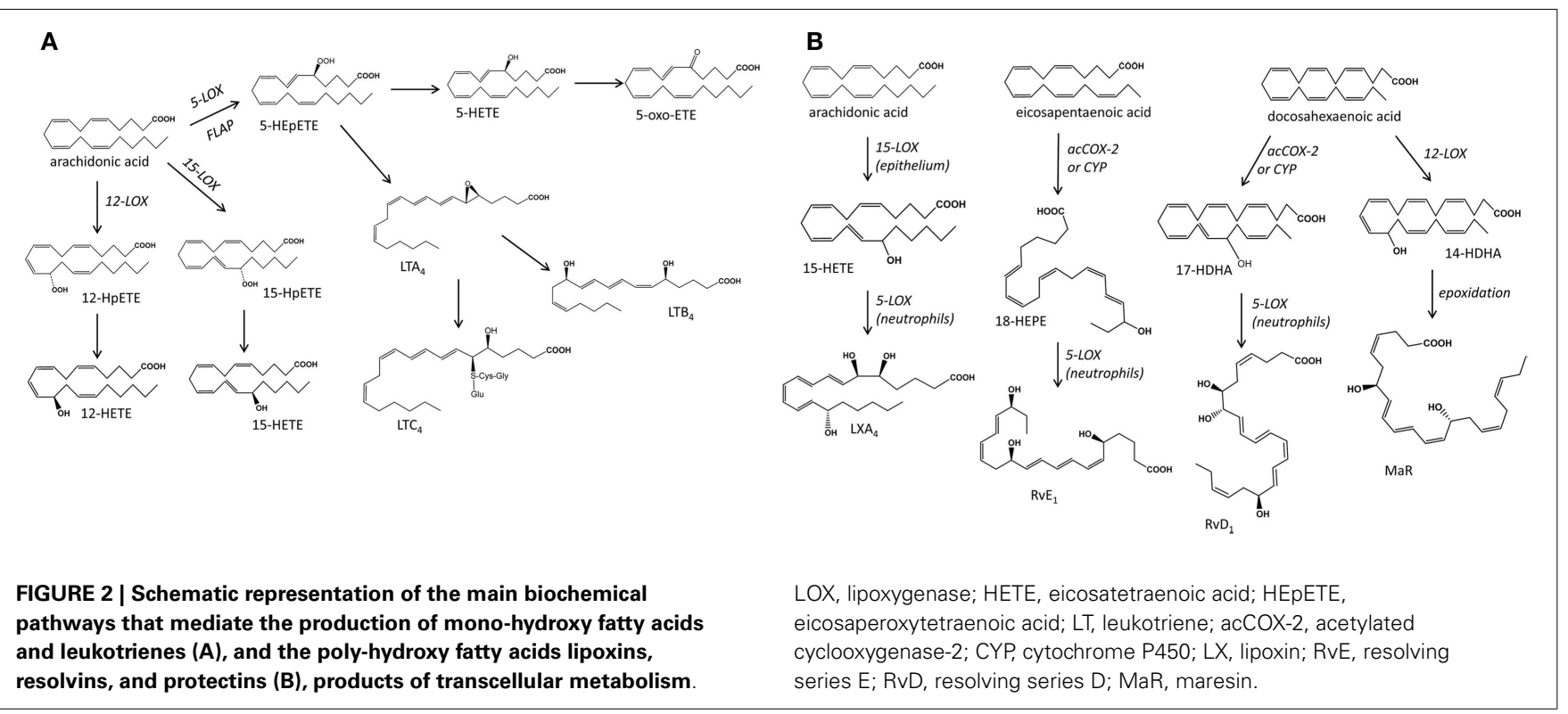

respectively. Pharmacological studies into their ligand-binding profiles and signal transduction pathways, and genetic analysis led to their classification into eight groups (EP1, EP2, EP3, EP4, DP1, FP, IP, and TP) although new developments have revealed the presence of a second PGD receptor, DP2, and the presence of heterodimers $(52,53)$. Overall, prostanoids are potent autacoids and their levels are controlled through enzymatic catabolism via dehydrogenations and reductions resulting in the formation of 


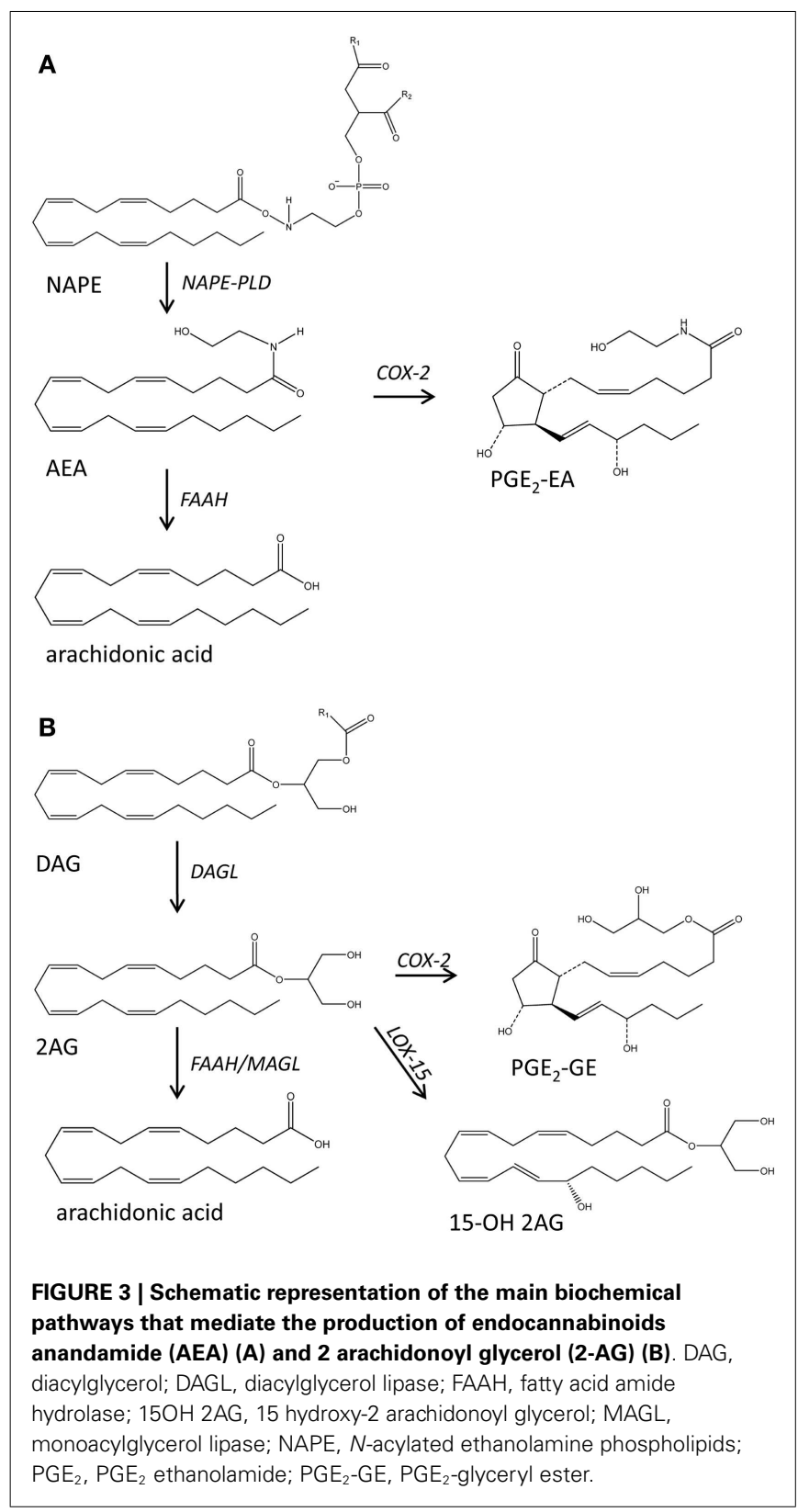

metabolites with significantly reduced bioactivities (e.g., 15-ketoand 13,14-dihydro-15-keto PGs) (54).

\section{LIPOXYGENASE-MEDIATED PRODUCTION OF LEUKOTRIENES AND OTHER HYDROXY FATTY ACIDS}

Lipoxygenases mediate the oxygenation of free fatty acids including AA and other PUFA. Their activities are commonly defined by their positional selectivity when they oxygenate AA and, following this system, the main mammalian LOX enzymes are defined as 5-, 12-, and 15-LOX. They catalyze the stereoselective insertion of $\mathrm{OH}$ in the $S$ configuration, with the exception of a mammalian skin-specific enzyme $12 R$-LOX. The products of LOX reactions are unstable hydroperoxides that are then reduced to hydroxy acids (55-57) (Figure 2). 5-LOX acts in concert with 5-lipoxygenase activating protein (FLAP) to metabolize AA to $5 S$-hydroperoxyeicosatetraenoic acid (HPETE) that is further reduced to $5 S$-HETE or dehydrated to $\mathrm{LTA}_{4}$, an unstable epoxide containing a conjugated triene system characteristic of all LT. $\mathrm{LTA}_{4}$ can be metabolized to $\mathrm{LTB}_{4}$ or form the cysteinyl LT, $\mathrm{LTC}_{4}, \mathrm{LTD}_{4}, \mathrm{LTE}_{4}$ following conjugation with reduced glutathione (58). 5S-HETE can be also enzymatically reduced to the 5-oxo-eicosatetraenoic acid (5-oxo-ETE), a chemoattractant mediator (59). Mammalian 12- and 15-LOX isozymes oxygenate a range of PUFA, both free and esterified in membrane phospholipids and lipoproteins (57), forming a multitude of monoand poly-hydroxy fatty acids: e.g., AA produces hydroxyeicosatetraenoic acids (HETE), EPA generates hydroxyeicosapentaenoic acids (HEPE), DHA produces docosanoids including hydroxydocosahexaenoic acids (HDHA), linoleic acid (LA; 18:2n-6) forms octadecanoids such as hydroxy octadecadienoic acids (HODE), DGLA forms hydroxyeicosatrienoic acids (HETrE), etc.

\section{CYTOCHROME P450 MEDIATED FATTY ACID EPOXIDES AND THEIR DERIVATIVES}

Cytochrome P450 mono-oxygenases relevant to PUFA metabolism catalyze epoxygenations and mid-chain and omegahydroxylations producing a range of LOX-like mono-hydroxy fatty acids (e.g., HETE, HEPE, HODE) although not necessarily of the $S$ configuration [reviewed in Ref. (35)]. Interestingly, partially inhibited COX-2 (e.g., acetylated COX-2 following treatment with aspirin) can also generate LOX-like products with the $\mathrm{OH}$ group at $R$ configuration, e.g., $15 R$-HETE from AA and $18 R$-HEPE from EPA (60). These metabolites are important in aspects of transcellular metabolism where sequential LOX/LOX or acetylated COX2/LOX or CYP/LOX reactions involving more than one cell types are involved in the formation of multi-hydroxy fatty acid species. These include the lipoxins (LX) that are tri-hydroxytetraeneproducts of AA, and the di- and tri-hydroxy-PUFA termed Rv, $\mathrm{PD}$, and maresins (MaR) that are derivatives of EPA and DHA. All these mediators are involved in inflammation and immunity exhibiting a range of protective roles (61-63).

\section{THE ENDOCANNABINOIDS}

The endocannabinoids anandamide (arachidonoyl ethanolamide, AEA) and 2-arachidonoyl glycerol (2AG) are derivatives of AA and act as endogenous ligands to the cannabinoid receptors CB1 and CB2 [reviewed in Ref. (36)]. This family of bioactive lipids has been extended to include other fatty acid ethanolamides and glycerols, while recent findings regarding their metabolism suggest a wider involvement in inflammation and immunity. The biochemical precursors of AEA and its congers are various $N$-acylated ethanolamine phospholipids (NAPE) that found in very low concentrations in the biological membranes and are hydrolyzed by NAPE-specific PLD or PLC-type lipases. 2AG production is mediated by PLC-diacylglycerol lipase. AEA and 2-AG can be deactivated via hydrolysis mediated by fatty acid amide hydrolases (FAAH) or can be metabolized by COX-2 to generated prostaglandin ethanolamides known as prostamides (e.g., $\mathrm{PGE}_{2}$ EA) and prostaglandin glyceryl esters (e.g. $\mathrm{PGE}_{2}-\mathrm{GE}$ ) (Figure 3) (52). LOX isozymes can also metabolize these lipids although the 
prevalence and bioactivities of the resulting mediators remain to be explored.

\section{EICOSANOIDS AND RELATED MEDIATORS IN T CELL FUNCTION/BIOLOGY \\ PROSTANOIDS}

It is now recognized that resting and activated $\mathrm{T}$ cells express the COX-1/-2 system (64-68). Although the constitutive COX-1 is not affected during $\mathrm{T}$ cell activation, the inducible COX-2 is upregulated as has been shown in studies with CD4+ cells, Jurkat $\mathrm{T}$ cells and adaptive Tregs (66-69). To date, very little is known about the exact profile of prostanoids produced by $\mathrm{T}$ cells with only a few studies reporting the production of $\mathrm{PGE}_{2}, \mathrm{PGD}_{2}$ and its dehydration product $15 \mathrm{~d}-\mathrm{PGJ}_{2}$, as well as low levels of TXA $(67,68,70)$. There is also very little information on the type of prostanoid synthases expressed in $\mathrm{T}$ cells, including evidence for H-PGDS and PGES in Tregs $(67,68)$. However, a number of studies have explored the role of $\mathrm{PGE}_{2}, \mathrm{PGD}_{2}, \mathrm{PGI}_{2}, \mathrm{PGF}_{2 \alpha}$, and TXA on various aspects of $\mathrm{T}$ cell function, showing that prostanoidmediated effects process through receptors and related signaling pathways expressed in most $\mathrm{T}$ cell populations and subtypes. Interestingly, it has been shown that treatment with AA upregulates the CXCR3/1 inducible chemokine receptors expressed in CD4+ T cells and increases their chemotactic responses through a COXrelated pathway (71), suggesting a potential role for this pathway in the regulation of $\mathrm{T}$ cell migration.

\section{$\mathrm{PGE}_{2}$}

Although considered to be a, primarily, pro-inflammatory eicosanoid, $\mathrm{PGE}_{2}$ can also mediate anti-inflammatory signals, and is a potent immunosuppressor (72). $\mathrm{PGE}_{2}$ is one of the beststudied bioactive lipids in $\mathrm{T}$ cell biology, exhibiting a multitude of effects. It is involved in the early stages of $\mathrm{T}$ cell development in the thymus, where it stimulates the differentiation of CD4+CD8+ thymocytes (73), while in later stages it regulates the development and balance of Th1, Th2, and Th17 subsets (74-76) and, overall, influences proliferation, differentiation, cytokine production, and apoptosis of mature $\mathrm{T}$ cells $(14,77-80)$. Interestingly, the activity of $\mathrm{PGE}_{2}$ on $\mathrm{T}$ cells appears to be concentrationdependent: while at low concentrations, it is involved in homeostatic events and inhibits the activation and differentiation of $\mathrm{T}$ lymphocytes, at high concentrations, $\mathrm{PGE}_{2}$ has the opposite effect, increasing $\mathrm{T}$ cell proliferation, and suppressing immune functions [recently reviewed in Ref. (81)]. For example, in ultraviolet radiation (UVR)-induced immunosuppression, impaired development of peripheral memory $\mathrm{T}$ cells can be attributed to UVR-induced $\mathrm{PGE}_{2}$ production (82).

Antigen presenting dendritic cells (DC) and macrophages secrete $\mathrm{PGE}_{2}$ and in this way can influence proliferation and differentiation of $\mathrm{CD} 4+$ and $\mathrm{CD} 8+$ cells, and direct the balance of Th1, Th2, and Th17 cell subtypes (14). $\mathrm{PGE}_{2}$ can also affect the maturation of DC and alter DC-produced cytokines, thus influencing the differentiation of T cell subtypes: for example, DC cells matured in the presence of $\mathrm{PGE}_{2}$ in vitro promote Th17 and inhibit Th1/Th2 polarization (78). $\mathrm{PGE}_{2}$ can also enhance the proliferation of $\mathrm{T}$ cells through the induction of costimulatory molecules OX40L, CD70, and 4-1BBL on DC (83), while other studies have reported that $\mathrm{PGE}_{2}$ inhibits the ability of DC to produce CCL19 and attract naive $\mathrm{T}$ cells (84). Interestingly, the ratio DC:T cells appears to be crucial in determining the overall immunogenic effect of $\mathrm{PGE}_{2}$ : it has been reported that at high DC:T cell ratios, $\mathrm{PGE}_{2}$-maturated DC cells inhibit the proliferation of T cells, while, when this cell ratio is low, an enhanced $\mathrm{T}$ cell stimulation is observed (85). A dose-dependent effect has also been observed in the way $\mathrm{PGE}_{2}$ mediates the balance Th1 to Th2 subtypes: high levels of $\mathrm{PGE}_{2}$ suppress Th1 cell differentiation and polarization, shifting the immune response toward a Th2 phenotype (79). These observations have been confirmed in vivo using COX-2 inhibitors (e.g., celecoxib) and COX-2 knockout models demonstrating that when $\mathrm{PGE}_{2}$ production is reduced, an increase in Th1 responses is observed [reviewed in Ref. (81)]. The regulation of Th2 cells by $\mathrm{PGE}_{2}$ is likely to impact in Th2-mediated immune disorders such as atopic dermatitis and asthma $(86,87)$. Finally, when $\mathrm{PGE}_{2}$ is produced by activated macrophages it reduces $\mathrm{T}$ cell activation and proliferation; this in turn leads to a reduction in cytokine production and consequent reduced stimulation of macrophages in a negative feed-back loop (72).

In vivo work has elucidated the role of $\mathrm{EP}$ receptors in mediating $\mathrm{PGE}_{2}$ effects. $\mathrm{PGE}_{2}$ produced by $\mathrm{DC}$ in the lymph node acts through the EP1 receptor to promote the differentiation of naive $\mathrm{T}$ cells to Th1 cells (88). Studies on the BALB/c mice, a strain showing propensity to generate Th2 responses, have shown that Th2 cells express high levels of EP2 and that $\mathrm{PGE}_{2}$ signaling through this receptor protects Th2 cells against activation induced cell death (77). Furthermore, in a model of experimental autoimmune encephalomyelitis (EAE), $\mathrm{PGE}_{2}$ signaling through $\mathrm{EP} 4$ was shown to exert a dual role: promoting immune inflammation through Th1 cell differentiation and Th17 cell expansion during the induction phase. In contrast, during the effector phase of the disease, it attenuated the access of these pathogenic $\mathrm{T}$ cells to the brain by protecting the blood brain barrier $(89,90)$.

$\mathrm{PGE}_{2}$-induced effects mediated via the EP2/EP4 receptors are linked to cAMP concentration and related signaling (53). In cytotoxic $\mathrm{T}$ cells, $\mathrm{PGE}_{2}$ and other cAMP activators trigger increased concentration of cAMP and this interferes with the cytoskeleton function and terminates cytotoxic $\mathrm{T}$ cell secretion and adhesion (91). Dietary interventions with $n-3$ and n-6 PUFA can alter the cell membrane composition with consequent changes in the concentration of $\mathrm{PGE}_{2}$ produced, as well as the prevalence of the less-inflammatory PGE species, $\mathrm{PGE}_{1}$ and $\mathrm{PGE}_{3}$ (44). Although frequently cited as anti-inflammatory, these species do not always appear to be different in their immunomodulatory properties: for example, studies have shown that both $\mathrm{PGE}_{2}$ and $\mathrm{PGE}_{1}$ suppress mitogen-induced blastogenesis in T cells, an effect confirmed with experiments using indomethacin, a non-specific COX inhibitor (92).

$\mathrm{PGE}_{2}$ ethanolamide appears to be also involved in the motility of $\mathrm{T}$ cells $(93,94)$ and recent work using imaging has identified $\mathrm{PGE}_{2}$ as an antagonist of the $\mathrm{T}$ cell migration stop signal (95). This activity was shown to be subset specific, with Th migration in response to IL-2 inhibited at $10-100 \mathrm{ng} / \mathrm{ml} \mathrm{PGE}_{2}$ in vitro, although, in the same experimental conditions, the migration of cytotoxic $\mathrm{T}$ cells was not affected $(96,97)$. $\mathrm{PGE}_{2}$ has also been suggested to inhibit the transendothelial migration of $\mathrm{T}$ cells through increased 
calcium and cAMP concentrations $(98,99)$. In rats, $\mathrm{PGE}_{2}$ was found to inhibit the migration of $\mathrm{T}$ cells across the microvascular retinal endothelial cells although it did not affect the expression of adhesion molecules on either endothelial or T cells (100). However, $\mathrm{PGE}_{2}$ at nanomolar to micromolar concentrations elicited migration of $\mathrm{T}$ cells in vitro and increased secretion matrix metalloproteinases (MMP); although MMP inhibitors suppressed the transmigration, the inhibition did not affect the $\mathrm{PGE}_{2}$-initiated $\mathrm{T}$ cell motility (101). Finally, overexpression of COX-2 in a mouse breast cancer model increased the recruitment of Tregs in the tumor, an effect mediated via EP2 and EP4 receptors (102).

\section{$\mathbf{P G D}_{2}$ and15d-PGJ}

$\mathrm{PGD}_{2}$ is considered an immunomodulatory prostaglandin and some of its cyclopentanone PG metabolites, such as 15-deoxy$\Delta^{12,14}-\mathrm{PGJ}_{2}\left(15 \mathrm{~d}-\mathrm{PGJ}_{2}\right)$, are endowed with anti-inflammatory activities $(49,103)$. Production of $\mathrm{PGD}_{2}$ has been detected in Th2 cells and this was linked to expression of H-PGDS, while L-PGDS has not been identified in any $\mathrm{T}$ cell subtype $(67,104,105)$. The downstream product of $\mathrm{PGD}_{2}$ dehydration, $15 \mathrm{~d}-\mathrm{PGJ}_{2}$, has also been detected in human $\mathrm{T}$ cell cultures (67).

$\mathrm{PGD}_{2}$ mediates its effects through two receptors DP1 and DP2, the latter better known as chemoattractant receptor-homologous molecule expressed on Th2 cells (CRTH2). DP1 belongs to the prostanoid family of receptors, signals through cAMP and has been detected in Th1, Th2, and CD8+ cells (106). DP2/CRTH2 has little similarity to prostanoid receptors and belongs to the cytokine receptor family; it signals through increased calcium and inhibition of cAMP and has been found to be preferentially expressed by activated Th2 cells mediating their recruitment and motility (106, 107). While $\mathrm{PGD}_{2}$ can signal through either receptor, findings to date indicate that $15 \mathrm{~d}-\mathrm{PGJ}_{2}$ activates only DP2 (103). It has been suggested that $\mathrm{PGH}_{2}$ may also be an agonist of DP2 (108). $\mathrm{PGD}_{2}$ and $15 \mathrm{~d}-\mathrm{PGJ}_{2}$ are also agonists of PPAR $\gamma$ and can induce differentiation of fibroblasts to adipocytes; this has been shown in the case of Grave's disease where it was reported that activated $\mathrm{T}$ cells drive fibroblast differentiation in ocular tissue through production of $\mathrm{PGD}_{2}$ and $15 \mathrm{~d}-\mathrm{PGJ}_{2}$, implying that $\mathrm{T}$ cell infiltrates can influence fat deposition in other tissues (67).

$\mathrm{PGD}_{2}$ can mediate different effects depending on the target receptor and related signaling events (109). DP1 can induce differentiation of Th2, whilst DP2/CRTH2 is mostly involved in their recruitment, although the two receptors may exert opposing effects, as examined in an animal model of contact hypersensitivity where DP2/CRTH2 appeared to mediate inflammatory events while DP1 was inhibitory (110). Furthermore, both receptors have been reported involved in T cell proliferation, and DP1 has been suggested to promote $\mathrm{T}$ cell apoptosis and downregulate immune responses, while DP2 has been reported to delay Th2 apoptosis (111). A potentially anti-inflammatory protective effect of 15$\mathrm{dPGJ}_{2}$ in pregnancy has been attributed to its suppression of Th1 response and promotion of Th2 immunity through DP2 (112).

Activation of Th2 cells by $\mathrm{PGD}_{2}$ is thought to occur predominantly through DP2/CRTH2 with concomitant increase in the production of cytokines and pro-inflammatory proteins (106, 113-115). $\mathrm{PGD}_{2}$ binding to this receptor is also very important for CD4+ T cell trafficking and motility $(116,117)$. When produced at high concentrations by mast cells, as seen in allergic inflammation, there is a consequent activation and recruitment of Th2 cells toward the $\mathrm{PGD}_{2}$ producing sites $(118,119)$. Activated T cells can also produce $\mathrm{PGD}_{2}$ and this may promote further accumulation of Th2 in the inflamed tissue $(107,116)$.

Finally, $\mathrm{PGD}_{2}$ has been shown to affect the maturation of monocyte derived DC impacting on their ability to stimulate naive $\mathrm{T}$ cells and favoring their differentiation toward Th2 cells $(120,121)$. Interestingly, age related increase in $\mathrm{PGD}_{2}$ levels have been associated with decreased DC migration and reduced $\mathrm{T}$ cell responses in a mouse model of respiratory infections, suggesting that inhibition of $\mathrm{PGD}_{2}$ functions may be an effective therapeutic approach (122).

\section{PGF $_{2 \alpha}$}

To date, there is very limited information on the contribution of this vasoactive prostaglandin on $\mathrm{T}$ cell function. There are no reports on the production of $\mathrm{PGF}_{2 \alpha}$ or expression of the relevant synthases on T lymphocytes. Early work exploring the involvement on PG on T cell locomotion considered the involvement of $\mathrm{PGF}_{2 \alpha}$ but this was not supported by the resulting data (93). However, a recent report on allergic lung inflammation presents evidence for the contribution of $\mathrm{PGF}_{2 \alpha}$ in Th17 cell differentiation, an autocrine effect mediated through cell surface FP receptors (123).

\section{$\mathrm{PGI}_{2}$}

$\mathrm{PGI}_{2}$ is best known as an inhibitor of platelet aggregation and potent vasodilator, while recent finding has shown its involvement in immune regulation with particular importance in airway inflammation. The IP receptor is expressed in a number of immune cells in the lung, including T lymphocytes of the Th1 and Th2 lineage $(124,125)$. However, there is very little information on the actual production of $\mathrm{PGI}_{2}$ by $\mathrm{T}$ cells with only some indirect evidence for possible transcellular biosynthesis operating between platelets and lymphocytes, and some recent work showing PGIS mRNA in an animal model of contact hypersensitivity $(125,126)$.

Studies in various models suggest that $\mathrm{PGI}_{2}$ is involved in regulating the balance of Th1 and Th2 responses, as well as promoting Th17 cell differentiation $(13,127)$. Work in a mouse model of asthma has shown that $\mathrm{PGI}_{2}$ produced by endothelial cells and signaling through the IP receptor prevents the recruitment of Th2 in the airways (128). However, a mouse model of contact hypersensitivity shows that in cutaneous disease $\mathrm{PGI}_{2}$-IP signaling raises intracellular cAMP concentration and promotes Th1 differentiation (125). Furthermore, $\mathrm{PGI}_{2}$ increased the ratio of IL-23/IL-12 leading to differentiation of Th17 cells and exacerbation of EAE in mice (129). Finally, the anti-inflammatory effect of $\mathrm{PGI}_{2}$ has been explored through analogs that reduced the production of pro-inflammatory cytokines and chemokines by DC, increased the production of anti-inflammatory IL-10, and inhibited their ability to stimulate CD4+ T cell proliferation (124).

\section{$T X A_{2}$}

Although production of $\mathrm{TXA}_{2}$ by $\mathrm{T}$ cells has been reported, albeit at very low levels, the expression of the relevant synthase has not yet been shown $(70,130)$. However, the TP receptor has been 
found in a range of $\mathrm{T}$ cell populations and a polymorphism identified in Th2 cells has been linked to aspirin-exacerbated respiratory disease (130-133). Work with human lymphocytes suggested that $\mathrm{TXA}_{2}$ is involved in the inhibition of $\mathrm{T}$ cell proliferation and related cytokine production (134). Following production of $\mathrm{TXA}_{2}$ by DC, stimulation in TP expression was observed and this appeared to be involved in the random movement of naive but not memory $\mathrm{T}$ cells, suggesting that $\mathrm{TXA}_{2}$ can mediate $\mathrm{DC}-\mathrm{T}$ cell interactions (130).

\section{LEUKOTRIENES, HYDROXY FATTY ACIDS, LIPOXINS, RESOLVINS, AND PROTECTINS}

Lipoxygenase isoforms identified in various $\mathrm{T}$ cell populations include 5-, 12-, and 15-LOX (135-138). Although some early studies suggested that externally provided AA could inhibit 5-LOX, recent reports have indicated that provision of substrate may be necessary for the synthesis of LTs $(135,139)$. There is evidence that 5-HETE, $\mathrm{LTA}_{4}$ and $\mathrm{LTB}_{4}$, and the cysteinyl LT LTC $4, \mathrm{LTD}_{4}$, and $\mathrm{LTE}_{4}$, are produced by human and animal primary $\mathrm{T}$ cells and cell lines $(43,135,138,139)$. Furthermore, the presence of 5-LOX and $12 / 15$-LOX would suggest the production of hydroperoxy- and hydroxy-PUFA by T cells. Nevertheless, there are not many studies examining the formation of such mediators and the majority of relevant reports focus on the effect of 12- and 15-HETE, LX, resolvins, and $\mathrm{PD}$ on $\mathrm{T}$ cell function.

\section{$L_{T} B_{4}$}

The main activity attributed to $\mathrm{LTB}_{4}$ is chemotaxis, a property mediated through the high affinity receptor BLT1 that is expressed in many CD4+ and CD8+ T cell subtypes (140-143). BLT1 is also important for homing events, as it enables the adhesion of $\mathrm{T}$ cells to epithelial cells, and appears of particular importance for the recruitment and direction of $\mathrm{T}$ cells to the airways in asthma $(141,144)$. Blockade of $\mathrm{LTB}_{4} /$ BLT1 pathway has also been shown to improve CD8+ T cell mediated colitis (145). Finally, $\mathrm{LTB}_{4}$ appears involved in Th17 cell differentiation, Th1 and Th2 proliferation, and cytokine production (146-149).

\section{$\operatorname{LTC}_{4}, \mathbf{L T D}_{4}, \mathrm{LTE}_{4}$}

The cysteinyl LT specific receptors CysLT1 and CysLT2 have been found to be expressed by peripheral blood T cells (150). Interestingly, it has been reported that resting Th2 cells display higher expression of the CysLT1 receptor compared to Th1 or activated Th2 cells, suggesting its involvement in Th2 cell differentiation $(151,152)$. Accordingly, in the presence of $\mathrm{PGD}_{2}, \mathrm{LTD}_{4}$ and $\mathrm{LTE}_{4}$ have been shown to enhance Th2 cell activation and cytokine production, in a more than additive effect (153).

Furthermore, $\mathrm{LTC}_{4}$ appears to induce T cell proliferation (154), while $\mathrm{LTC}_{4}$-maturated DC appear to stimulate $\mathrm{CD} 4+$ responses and induce cytotoxic T cells in vitro without concomitant recruitment of Tregs (155).

\section{5-HETE and 5-oxo-ETE}

Oxidative stress appears to stimulate the metabolism of 5-HETE to 5-oxo-ETE in peripheral blood lymphocytes, although the role of this lipid mediator in T cell function is not clear $(156,157)$.

\section{2-, 15-HETE}

12-HETE has been involved in T cell function, with particular relevance to allergic disease. Although 12(S)-HETE is a neutrophil chemoattractant it does not appear to have a similar effect on $\mathrm{T}$ cells. Work on skin-derived lymphocytes involved in psoriasis has shown that $12(R)$-HETE, a $12 R$-LOX product found in psoriatic skin, has modest chemotactic properties for T cells but is less potent than $\operatorname{LTB}_{4}(158,159)$. Furthermore, it has been shown that inhibition of 12/15-LOX enhanced the production of Th2 cytokines and attenuated the development of allergic inflammation in a mouse model of allergic lung disease, whilst delivery of 12(S)-HETE had the opposite effect (136). Increased levels of 12-HETE were also associated with metabolic changes in $\mathrm{T}$ cells leading to development of autoimmune disease (137).

It has been reported that 15-HETE regulates $\mathrm{T}$ cell division and displays anti-proliferative effects on a leukemia $\mathrm{T}$ cell line (160-162). Metabolism of 15-HETE through $\beta$-oxidation has been observed in blood $\mathrm{T}$ cells leading to the hypothesis that the resulting $\beta$-hydroxy acids and their oxidized and decarboxylated products may play a role in T cell biology (163). 15-LOX metabolites have also been involved in Th1 responses in a mouse model of Th1 allergic inflammation induced by double-stranded RNA (164).

\section{Lipoxins}

Although not directly produced by T cells, LXA4 has been shown to interact with the $\mathrm{LTB}_{4}$ receptor expressed in T cells $(165,166)$. Aspirin-triggered $\mathrm{LXA}_{4}$ and $\mathrm{LXB}_{4}$, and stable analogs, inhibited $\mathrm{TNF} \alpha$ production by human peripheral blood $\mathrm{T}$ cells suggesting the involvement of these metabolites in T cell mediated inflammation (167). Finally, $\mathrm{LXA}_{4}$ appears to be involved in Treg-mediated tumor protection through the induction of myeloid suppressor cells, as shown in a murine liver cancer model (168).

\section{Resolvins and protectins}

These products of EPA and DHA are formed through transcellular metabolism and some of their anti-inflammatory and proresolution effects are mediated through their effects on $\mathrm{T}$ cells. It has been reported that PD1 is formed by Th2-skewed peripheral blood mononuclear cells and appeared to block T cell migration, inhibit TNF $\alpha$ and IF $\gamma$ secretion, and promote apoptosis in vivo (169). Reduction of CD4+ and CD8+ T cell infiltrates and CD4+ $\mathrm{T}$ cell-produced cytokines was also observed in a mouse model of DNFB-induced atopic dermatitis treated with RvE1 (170). Furthermore, RvE1-treated bone marrow-derived DC appear to induce apoptosis of T cells, and it has been suggested that instead of migrating to the lymph nodes they remain on the inflammatory sites targeting the infiltrating effector T cells (171). RvE1 has also been shown to reduce the influx of Th1 and Th17 cells in the cornea of a mouse model of stromal keratitis, a virally induced immunopathological disease; it has been suggested that this may have contributed to a significant reduction in lesions observed (172).

\section{ENDOCANNABINOIDS AND CONGENERS}

The endocannabinoid system is considered an important regulator of the immune response with AEA, 2AG, and related enzymes and receptors being involved in T cell function (173-176). Production of AEA and 2AG have been shown in human T lymphocytes 
(177, 178), while the receptors CB1 and CB2 have been identified in primary $\mathrm{T}$ cells and $\mathrm{T}$ cell lines where their expression is stimulated upon activation $(179,180)$. In particular, the CB2 receptor has been shown to mediate the inhibition of mixed lymphocyte reactions by cannabinoids and is of interest for the development of novel chemotherapeutic approaches to prolong graft survival (181). Furthermore, CB2 has been suggested as an important factor for the formation of $\mathrm{T}$ cell subsets including splenic memory CD4+ cells and natural killer T cells (182). Interestingly, a common CB2 gene polymorphism has been linked to reduced immune modulation by endocannabinoids and may be a risk factor for autoimmune disorders (183). Finally, FAAH and monoacylglycerol lipase (MAGL) are also present in human $\mathrm{T}$ lymphocytes (179). FAAH appears to play a protective role controlling the levels of AEA in pregnancy as well as immune-mediated liver inflammation $(178,184)$.

\section{AEA and congeners}

Work with activated primary human $\mathrm{T}$ lymphocytes has shown that AEA can suppress $\mathrm{T}$ cell proliferation and cytokine release in a CB2-dependent manner, without exerting cytotoxic effects $(185,186)$. However, other studies suggested that AEA inhibits T cell proliferation and induces apoptosis through a mechanism that may not be receptor mediated but most probably related to lipid rafts $(187,188)$.

The immunosuppressive effect of AEA extends to Th17 cell and this is of particular interest for the development of immunotherapeutic approaches (186). Endogenous AEA or inhibition of FAAH leading to increased AEA levels, were effective in reducing cytokine levels, decreased liver injury, and increased numbers of Treg cells in a murine model of immune-mediated liver inflammation (184). AEA inhibited the migration of CD8 $+\mathrm{T}$ cells in a collagen-based migration assay, again through the CB2 receptor (189). However, a study evaluating the direct anti-cancer potential of AEA, reported no effect on lymphocyte proliferation or Treg generation or cytokine production (190). In contrast, other studies have reported proinflammatory effects by AEA. In a mouse model of atherosclerosis, reduced levels of FAAH that resulted in increased AEA and its congeners, palmitoyl- and oleoyl-ethanolamide, were accompanied by reduced $\mathrm{CD} 4+\mathrm{FoxP} 3+$ regulatory $\mathrm{T}$ cells, suggesting a pro-inflammatory effect on the overall immune response (191). In addition, AEA appears to promote Th1 immunity as shown in a model of sensitization where it was reported to induce DC activation and IFN $\gamma$ production (192). Finally, a recent study with bimatoprost suggested that this prostamide can induce calcium signaling in human T cells (193).

\section{$2 A G$}

The chemotactic properties of $2 \mathrm{AG}$ are also mediated through the $\mathrm{CB} 2$ receptor and this has been shown in various immune cells including migration of splenocytes (194), homing of B cells (195), and motility of human natural killer cells (196). When this potential was assessed in activated $\mathrm{T}$ lymphocytes, it was reported that although $2 \mathrm{AG}$ did not induce $\mathrm{T}$ cell migration, it inhibited migratory responses toward the chemokine CXCL12, suggesting a possible regulatory role in T cell migration (179). Furthermore, 2AG can act as DC chemoattractant and indirectly shift the memory response toward a Th1 phenotype in a CB2mediated fashion (197). 2AG can also suppress IL-2 production in Jurkat cells through PPAR- $\gamma$ activation and independently of CB1 and CB2-mediated signaling (198). The contribution of a COX-2 metabolite of $2 \mathrm{AG}$ has also been considered by recent reports confirming that the 15-deoxy-delta $(1)(2),(1)(4)-\mathrm{PGJ}_{2}$ glycerol ester $\left(15 \mathrm{~d}-\mathrm{PG} \mathrm{J}_{2}-\mathrm{GE}\right)$ is a PPAR- $\gamma$ ligand that suppresses IL-2 production in activated Jurkat cells $(111,199)$.

\section{CONCLUDING REMARIS}

While current evidence support a key role for PUFA-derived bioactive lipids in the regulation of $\mathrm{T}$ cell immunity (Table $\mathbf{1}$ ), the complexity of their biological properties and the lack of a comprehensive understanding of their exact contribution to different stages of the immune response hinders the identification of mediators of interest either as markers or as target compounds for drug development. In general, it appears that lipid mediators regulate $\mathrm{T}$ helper cell polarization into Th1/Th2 and Th17 cells, a key event in many immune-mediated diseases. Despite the molecular mechanisms for this effect and the regulatory role of these lipids on other T cell functions have yet to be explored, an extensive number of studies in mice and humans underscore their therapeutic potential.

This concept is supported by the large number of studies using their precursor fatty acids. Of particular importance is the focus on $n$-3 PUFA that have been explored as anti-inflammatory and immune-protective agents for a range of diseases and relevant experimental models including psoriasis, rheumatoid arthritis, and atherosclerosis $(32,33,200)$. A recent study has shown that dietary n-3 PUFA favorably modulate intestinal inflammation in part by downregulating pathogenic T cell responses (201). The Fat1 mouse, a genetic model that synthesizes long-chain $n$-3 PUFA de novo, was shown to be relatively resistant to colitis induction due to a reduced differentiation of Th17 cells and related cytokines (202). The immunoregulatory potential of a number of fatty acids has been reported over the years including that of DGLA and GLA (203), stearidonic acid (204) as well as various CLA mixtures used for inflammatory bowel syndrome and human Crohn's disease (205). Parenteral administration of fatty acids has been shown to ameliorate disease via immunomodulatory effect in a model of rat sepsis (206), A randomized study in patients awaiting carotid endarterectomy showed that $n$-3 PUFA ethyl esters are incorporated into advanced atherosclerotic plaques and higher plaque EPA is associated with decreased plaque inflammation and T cell infiltration, and increased stability following dietary supplementation with EPA (207).

Furthermore, altering the profile of lipid mediators to strengthen the responses of $\mathrm{T}$ cells may be of value to cancer immunotherapy and could result in the development of potent and/or less toxic therapeutics. For example, it is well-documented that most tumors express $\mathrm{PGE}_{2}$ and this can contribute to immune suppression $(103,208)$. Pharmacological inhibition of $\mathrm{PGE}_{2}$ via non-steroidal anti-inflammatory drugs or EP receptor agonists could be supported or even replaced by systemic administration of EPA, precursor of the less potent eicosanoid $\mathrm{PGE}_{3}$ and the antiinflammatory resolving series $\mathrm{E}(\mathrm{RvE})$ that can tone down the 
Table 1 | Summary of the main immunoregulatory roles of bioactive lipid mediators related to T cell function and biology.

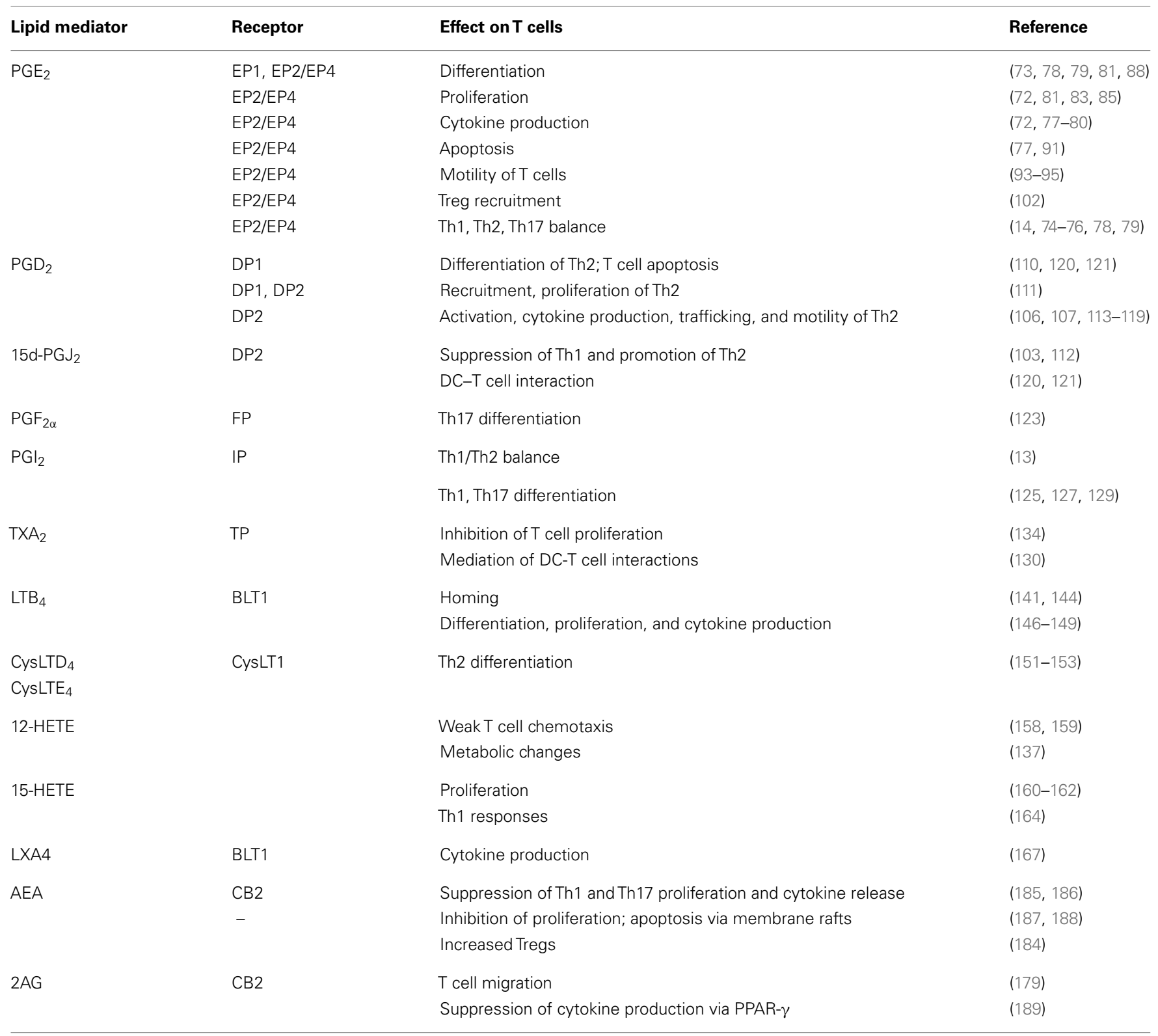

$\mathrm{PGE}_{2}$-mediated effects. Finally, a large number of other investigations have reported that immunonutrition with fatty acids leads to amelioration of a variety of immune-mediated disease by targeting $\mathrm{T}$ cell function. Examples include studies showing that the use of $n$-3 PUFA can improve lung injury and sepsis in animal models, and reduce infectious complications in patients undergoing major surgery and following severe trauma (209-211), while other reports draw attention to the contribution of fatty acids and their mediators in vaccine-induced immunity in infants, the prevention of experimental autoimmune encephalomyelitis through inhibition of Th1/Th17 differentiation by DHA, EPA-mediated protection of cardiac allografts, and amelioration of contact dermatitis following DHA and AA supplements (212-215).
Overall, there is a strong case for further developing therapeutic approaches based on the use of bioactive lipids as immunomodulators. The unmet challenge to fully exploit their therapeutic potential will be to unravel the circuits and molecular mechanisms by which these powerful mediators impact on $\mathrm{T}$ cell-mediated immunity.

\section{ACKNOWLEDGMENTS}

Research support provided by the Wellcome Trust (Anna Nicolaou: WT094028) and British Heart Foundation (Claudio Mauro: FS/12/38/29640 and Federica Marelli-Berg: RG/09/002/2642) is gratefully acknowledged. We thank Dr. Sharon A. Murphy for her contribution to the figures shown in the manuscript. 


\section{REFERENCES}

1. Wang R, Green DR. Metabolic checkpoints in activated T cells. Nat Immunol (2012) 13(10):907-15. doi:10.1038/ni.2386

2. Schumacher TN, Gerlach C, van Heijst JW. Mapping the life histories of T cells. Nat Rev Immunol (2010) 10(9):621-31. doi:10.1038/nri2822

3. Green DR. Overview: apoptotic signaling pathways in the immune system. Immunol Rev (2003) 193:5-9. doi:10.1034/j.1600-065X.2003.00045.X

4. Wang R, Green DR. The immune diet: meeting the metabolic demands of lymphocyte activation. F1000 Biol Rep (2013) 4:9. doi:10.3410/B4-9

5. Wang R, Dillon CP, Shi LZ, Milasta S, Carter R, Finkelstein D, et al. The transcription factor Myc controls metabolic reprogramming upon $\mathrm{T}$ lymphocyte activation. Immunity (2012) 35(6):871-82. doi:10.1016/j.immuni.2011.09.021

6. Gerriets VA, Rathmell JC. Metabolic pathways in T cell fate and function. Trends Immunol (2012) 33(4):168-73. doi:10.1016/j.it.2012.01.010

7. Marelli-Berg FM, Fu H, Mauro C. Molecular mechanisms of metabolic reprogramming in proliferating cells: implications for T-cell-mediated immunity. Immunology (2012) 136(4):363-9. doi:10.1111/j.1365-2567.2012.03583.x

8. Mauro C, Fu H, Marelli-Berg FM. T cell trafficking and metabolism: novel mechanisms and targets for immunomodulation. Curr Opin Pharmacol (2012) 12(4):452-7. doi:10.1016/j.coph.2012.02.018

9. Powell JD, Delgoffe GM. The mammalian target of rapamycin: linking $\mathrm{T}$ cell differentiation, function, and metabolism. Immunity (2011) 33(3):301-11. doi:10.1016/j.immuni.2010.09.002

10. Peter C, Waldmann H, Cobbold SP. mTOR signalling and metabolic regulation of T cell differentiation. Curr Opin Immunol (2010) 22(5):655-61. doi:10.1016/j.coi.2010.08.010

11. Jones RG, Thompson CB. Revving the engine: signal transduction fuels $\mathrm{T}$ cell activation. Immunity (2007) 27(2):173-8. doi:10.1016/j.immuni.2007.07.008

12. Yamane H, Paul WE. Early signaling events that underlie fate decisions of naive CD4(+) T cells toward distinct T-helper cell subsets. Immunol Rev (2013) 252(1):12-23. doi:10.1111/imr.12032

13. Boswell MG, Zhou W, Newcomb DC, Peebles RS Jr. PGI2 as a regulator of CD4+ subset differentiation and function. Prostaglandins Other Lipid Mediat (2011) 96(1-4):21-6. doi:10.1016/j.prostaglandins.2011.08.003

14. Li H, Edin ML, Gruzdev A, Cheng J, Bradbury JA, Graves JP, et al. Regulation of T helper cell subsets by cyclooxygenases and their metabolites. Prostaglandins Other Lipid Mediat (2013) 104-105:74-83. doi:10.1016/j.prostaglandins.2012. 11.002

15. Macintyre AN, Finlay D, Preston G, Sinclair LV, Waugh CM, Tamas P, et al. Protein kinase $\mathrm{B}$ controls transcriptional programs that direct cytotoxic $\mathrm{T}$ cell fate but is dispensable for T cell metabolism. Immunity (2011) 34(2):224-36. doi:10.1016/j.immuni.2011.01.012

16. Cornish GH, Sinclair LV, Cantrell DA. Differential regulation of T-cell growth by IL-2 and IL-15. Blood (2006) 108(2):600-8. doi:10.1182/blood-2005-124827

17. Shi LZ, Wang R, Huang G, Vogel P, Neale G, Green DR, et al. HIFlalphadependent glycolytic pathway orchestrates a metabolic checkpoint for the differentiation of TH17 and Treg cells. J Exp Med (2011) 208(7):1367-76. doi:10.1084/jem.20110278

18. Michalek RD, Gerriets VA, Jacobs SR, Macintyre AN, MacIver NJ, Mason EF, et al. Cutting edge: distinct glycolytic and lipid oxidative metabolic programs are essential for effector and regulatory CD4+ T cell subsets. J Immunol (2011) 186(6):3299-303. doi:10.4049/jimmunol.1003613

19. van der Windt GJ, Everts B, Chang CH, Curtis JD, Freitas TC, Amiel E, et al. Mitochondrial respiratory capacity is a critical regulator of CD8+ T cell memory development. Immunity (2012) 36(1):68-78. doi:10.1016/j.immuni.2011. 12.007

20. Shaikh SR, Jolly CA, Chapkin RS. n-3 Polyunsaturated fatty acids exert immunomodulatory effects on lymphocytes by targeting plasma membrane molecular organization. Mol Aspects Med (2012) 33(1):46-54. doi:10.1016/j. mam.2011.10.002

21. Calder PC. The relationship between the fatty acid composition of immune cells and their function. Prostaglandins Leukot Essent Fatty Acids (2008) 79(3-5):101-8. doi:10.1016/j.plefa.2008.09.016

22. Kew S, Mesa MD, Tricon S, Buckley R, Minihane AM, Yaqoob P. Effects of oils rich in eicosapentaenoic and docosahexaenoic acids on immune cell composition and function in healthy humans. Am J Clin Nutr (2004) 79(4):674-81.
23. Petursdottir DH, Hardardottir I. Dietary fish oil decreases secretion of T helper (Th) 1-type cytokines by a direct effect on murine splenic T cells but enhances secretion of a Th2-type cytokine by an effect on accessory cells. Br J Nutr (2009) 101(7):1040-6. doi:10.1017/S0007114508048290

24. Thies F, Nebe-von-Caron G, Powell JR, Yaqoob P, Newsholme EA, Calder PC. Dietary supplementation with gamma-linolenic acid or fish oil decreases T lymphocyte proliferation in healthy older humans. J Nutr (2001) 131(7):1918-27.

25. Verlengia R, Gorjao R, Kanunfre CC, Bordin S, Martins De Lima T, Martins EF, et al. Comparative effects of eicosapentaenoic acid and docosahexaenoic acid on proliferation, cytokine production, and pleiotropic gene expression in Jurkat cells. J Nutr Biochem (2004) 15(11):657-65. doi:10.1016/j.jnutbio.2004. 04.008

26. Shaikh SR, Edidin M. Immunosuppressive effects of polyunsaturated fatty acids on antigen presentation by human leukocyte antigen class I molecules. J Lipid Res (2007) 48(1):127-38. doi:10.1194/jlr.M600365-JLR200

27. Jaudszus A, Gruen M, Watzl B, Ness C, Roth A, Lochner A, et al. Evaluation of suppressive and pro-resolving effects of EPA and DHA in human primary monocytes and T-helper cells. J Lipid Res (2013) 54(4):923-35. doi:10.1194/jlr.P031260

28. Grimminger F, Grimm H, Fuhrer D, Papavassilis C, Lindemann G, Blecher C, et al. Omega-3 lipid infusion in a heart allotransplant model. Shift in fatty acid and lipid mediator profiles and prolongation of transplant survival. Circulation (1996) 93(2):365-71. doi:10.1161/01.CIR.93.2.365

29. van der Heide JJ, Bilo HJ, Donker JM, Wilmink JM, Tegzess AM. Effect of dietary fish oil on renal function and rejection in cyclosporine-treated recipients of renal transplants. N Engl J Med (1993) 329(11):769-73. doi:10.1056/ NEJM199309093291105

30. Iwami D, Zhang Q, Aramaki O, Nonomura K, Shirasugi N, Niimi M. Purified eicosapentaenoic acid induces prolonged survival of cardiac allografts and generates regulatory T cells. Am J Transplant (2009) 9(6):1294-307. doi:10.1111/j.1600-6143.2009.02641.x

31. Iwami D, Nonomura K, Shirasugi N, Niimi M. Immunomodulatory effects of eicosapentaenoic acid through induction of regulatory $\mathrm{T}$ cells. Int Immunopharmacol (2011) 11(3):384-9. doi:10.1016/j.intimp.2010.11.035

32. Kendall AC, Nicolaou A. Bioactive lipid mediators in skin inflammation and immunity. Prog Lipid Res (2013) 52(1):141-64. doi:10.1016/j.plipres.2012. 10.003

33. Hirata T, Narumiya S. Prostanoids as regulators of innate and adaptive immunity. Adv Immunol (2013) 116:143-74. doi:10.1016/B978-0-12-3943002.00005-3

34. Harizi H, Corcuff JB, Gualde N. Arachidonic-acid-derived eicosanoids: roles in biology and immunopathology. Trends Mol Med (2008) 14(10):461-9. doi:10.1016/j.molmed.2008.08.005

35. Massey KA, Nicolaou A. Lipidomics of polyunsaturated-fatty-acid-derived oxygenated metabolites. Biochem Soc Trans (2012) 39(5):1240-6. doi:10.1042/ BST0391240

36. Ueda N, Tsuboi K, Uyama T. Metabolism of endocannabinoids and related N-acylethanolamines: canonical and alternative pathways. FEBS J (2013) 280(9):1874-94. doi:10.1111/febs.12152

37. Dennis EA, Cao J, Hsu YH, Magrioti V, Kokotos G. Phospholipase A2 enzymes: physical structure, biological function, disease implication, chemical inhibition, and therapeutic intervention. Chem Rev (2011) 111(10):6130-85 doi: $10.1021 / \mathrm{cr} 200085 \mathrm{w}$

38. Tessier C, Hichami A, Khan NA. Implication of three isoforms of PLA(2) in human T-cell proliferation. FEBS Lett (2002) 520(1-3):111-6. doi:10.1016/ S0014-5793(02)02779-5

39. Hichami A, Joshi B, Simonin AM, Khan NA. Role of three isoforms of phospholipase A2 in capacitative calcium influx in human T-cells. Eur J Biochem (2002) 269(22):5557-63. doi:10.1046/j.1432-1033.2002.03261.x

40. Burgermeister E, Endl J, Scheuer WV. Activation of cytosolic phospholipase A2 in human T-lymphocytes involves inhibitor-kappaB and mitogen-activated protein kinases. Eur J Pharmacol (2003) 466(1-2):169-80. doi:10.1016/S00142999(03)01492-4

41. Roshak AK, Capper EA, Stevenson C, Eichman C, Marshall LA. Human calcium-independent phospholipase A2 mediates lymphocyte proliferation. J Biol Chem (2000) 275(46):35692-8. doi:10.1074/jbc.M002273200 
42. Le Gouvello S, Colard O, Theodorou I, Bismuth G, Tarantino N, Debre P. CD2 triggering stimulates a phospholipase $\mathrm{A} 2$ activity beside the phospholipase $\mathrm{C}$ pathway in human T lymphocytes. J Immunol (1990) 144(6):2359-64.

43. Cifone MG, Cironi L, Santoni A, Testi R. Diacylglycerol lipase activation and 5-lipoxygenase activation and translocation following TCR/CD3 triggering in T cells. Eur J Immunol (1995) 25(4):1080-6. doi:10.1002/eji.1830250433

44. Calder PC. Polyunsaturated fatty acids and inflammatory processes: new twists in an old tale. Biochimie (2009) 91(6):791-5. doi:10.1016/j.biochi.2009.01.008

45. Murakami M, Kudo I. Prostaglandin E synthase: a novel drug target for inflammation and cancer. Curr Pharm Des (2006) 12(8):943-54. doi:10.2174/ 138161206776055912

46. Hara S, Kamei D, Sasaki Y, Tanemoto A, Nakatani Y, Murakami M. Prostaglandin E synthases: understanding their pathophysiological roles through mouse genetic models. Biochimie (2010) 92(6):651-9. doi:10.1016/ j.biochi.2010.02.007

47. Urade Y, Eguchi N. Lipocalin-type and hematopoietic prostaglandin D synthases as a novel example of functional convergence. Prostaglandins Other Lipid Mediat (2002) 6(8-69):375-82. doi:10.1016/S0090-6980(02) 00042-4

48. Surh YJ, Na HK, Park JM, Lee HN, Kim W, Yoon IS, et al. 15-Deoxydelta(1)(2),(1)(4)-prostaglandin J(2), an electrophilic lipid mediator of anti-inflammatory and pro-resolving signaling. Biochem Pharmacol (2011) 82(10):1335-51. doi:10.1016/j.bcp.2011.07.100

49. Scher JU, Pillinger MH. 15d-PGJ2: the anti-inflammatory prostaglandin? Clin Immunol (2005) 114(2):100-9. doi:10.1016/j.clim.2004.09.008

50. Watanabe K. Prostaglandin F synthase. Prostaglandins Other Lipid Mediat (2002) 6(8-69):401-7. doi:10.1016/S0090-6980(02)00044-8

51. Cathcart MC, Reynolds JV, O'Byrne KJ, Pidgeon GP. The role of prostacyclin synthase and thromboxane synthase signaling in the development and progression of cancer. Biochim Biophys Acta (2010) 1805(2):153-66. doi:10.1016/j.bbcan.2010.01.006

52. Woodward DF, Jones RL, Narumiya S. International union of basic and clinical pharmacology. LXXXIII: classification of prostanoid receptors, updating 15 years of progress. Pharmacol Rev (2012) 63(3):471-538. doi:10.1124/pr.110. 003517

53. Breyer RM, Bagdassarian CK, Myers SA, Breyer MD. Prostanoid receptors: subtypes and signaling. Annu Rev Pharmacol Toxicol (2001) 41:661-90. doi:10.1146/annurev.pharmtox.41.1.661

54. Tai HH, Ensor CM, Tong M, Zhou H, Yan F. Prostaglandin catabolizing enzymes. Prostaglandins Other Lipid Mediat (2002) 6(8-69):483-93. doi:10. 1016/S0090-6980(02)00050-3

55. Brash AR. Lipoxygenases: occurrence, functions, catalysis, and acquisition of substrate. J Biol Chem (1999) 274(34):23679-82. doi:10.1074/jbc.274.34. 23679

56. Dobrian AD, Lieb DC, Cole BK, Taylor-Fishwick DA, Chakrabarti SK, Nadler JL. Functional and pathological roles of the 12- and 15-lipoxygenases. Prog Lipid Res (2011) 50(1):115-31. doi:10.1016/j.plipres.2010.10.005

57. Kuhn H, O'Donnell VB. Inflammation and immune regulation by $12 / 15-$ lipoxygenases. Prog Lipid Res (2006) 45(4):334-56. doi:10.1016/j.plipres.2006. 02.003

58. Murphy RC, Gijon MA. Biosynthesis and metabolism of leukotrienes. Biochem $J$ (2007) 405(3):379-95. doi:10.1042/BJ20070289

59. Powell WS, Rokach J. Biochemistry, biology and chemistry of the 5lipoxygenase product 5-oxo-ETE. Prog Lipid Res (2005) 44(2-3):154-83. doi:10.1016/j.plipres.2005.04.002

60. Lecomte M, Laneuville O, Ji C, DeWitt DL, Smith WL. Acetylation of human prostaglandin endoperoxide synthase-2 (cyclooxygenase-2) by aspirin. J Biol Chem (1994) 269(18):13207-15.

61. Claria J, Lee MH, Serhan CN. Aspirin-triggered lipoxins (15-epi-LX) are generated by the human lung adenocarcinoma cell line (A549)-neutrophil interactions and are potent inhibitors of cell proliferation. Mol Med (1996) 2(5):583-96.

62. Serhan CN, Hong S, Gronert K, Colgan SP, Devchand PR, Mirick G, et al. Resolvins: a family of bioactive products of omega-3 fatty acid transformation circuits initiated by aspirin treatment that counter proinflammation signals. J Exp Med (2002) 196(8):1025-37. doi:10.1084/jem.20020760

63. Serhan CN, Yang R, Martinod K, Kasuga K, Pillai PS, Porter TF, et al. Maresins: novel macrophage mediators with potent antiinflammatory and proresolving actions. J Exp Med (2009) 206(1):15-23. doi:10.1084/jem.20081880
64. Chacon P, Vega A, Monteseirin J, El Bekay R, Alba G, Perez-Formoso JL, et al. Induction of cyclooxygenase-2 expression by allergens in lymphocytes from allergic patients. Eur J Immunol (2005) 35(8):2313-24. doi:10.1002/eji. 255590583

65. Xu L, Zhang L, Yi Y, Kang HK, Datta SK. Human lupus T cells resist inactivation and escape death by upregulating COX-2. Nat Med (2004) 10(4):411-5. doi:10.1038/nm1005

66. Iniguez MA, Martinez-Martinez S, Punzon C, Redondo JM, Fresno M. An essential role of the nuclear factor of activated $\mathrm{T}$ cells in the regulation of the expression of the cyclooxygenase-2 gene in human T lymphocytes. J Biol Chem (2000) 275(31):23627-35. doi:10.1074/jbc.M001381200

67. Feldon SE, O'Loughlin CW, Ray DM, Landskroner-Eiger S, Seweryniak KE, Phipps RP. Activated human T lymphocytes express cyclooxygenase- 2 and produce proadipogenic prostaglandins that drive human orbital fibroblast differentiation to adipocytes. Am J Pathol (2006) 169(4):1183-93. doi:10.2353/ ajpath.2006.060434

68. Mahic M, Yaqub S, Johansson CC, Tasken K, Aandahl EM. FOXP3+CD4+CD25+ adaptive regulatory $\mathrm{T}$ cells express cyclooxygenase-2 and suppress effector $\mathrm{T}$ cells by a prostaglandin E2-dependent mechanism. J Immunol (2006) 177(1):246-54.

69. Pablos JL, Santiago B, Carreira PE, Galindo M, Gomez-Reino JJ. Cyclooxygenase-1 and -2 are expressed by human T cells. Clin Exp Immunol (1999) 115(1):86-90. doi:10.1046/j.1365-2249.1999.00780.x

70. Genaro AM, Sterin-Borda L, Gorelik G, Borda E. Prostanoids synthesis in lymphocyte subpopulations by adrenergic and cholinergic receptor stimulation. Int J Immunopharmacol (1992) 14(7):1145-51. doi:10.1016/0192-0561(92) 90049-Q

71. Gasser O, Schmid TA, Zenhaeusern G, Hess C. Cyclooxygenase regulates cell surface expression of CXCR3/1-storing granules in human CD4+ T cells. J Immunol (2006) 177(12):8806-12.

72. Kalinski P. Regulation of immune responses by prostaglandin E2. J Immunol (2011) 188(1):21-8. doi:10.4049/jimmunol.1101029

73. Rocca B, Spain LM, Pure E, Langenbach R, Patrono C, FitzGerald GA. Distinct roles of prostaglandin $\mathrm{H}$ synthases 1 and 2 in T-cell development. J Clin Invest (1999) 103(10):1469-77. doi:10.1172/JCI6400

74. Barrie A, Khare A, Henkel M, Zhang Y, Barmada MM, Duerr R, et al. Prostaglandin E2 and IL-23 plus IL-1beta differentially regulate the Th1/Th17 immune response of human CD161(+) CD4(+) memory T cells. Clin Transl Sci (2011) 4(4):268-73. doi:10.1111/j.1752-8062.2011.00300.x

75. Li H, Edin ML, Bradbury JA, Graves JP, DeGraff LM, Gruzdev A, et al. Cyclooxygenase-2 inhibits $\mathrm{T}$ helper cell type 9 differentiation during allergic lung inflammation via down-regulation of IL-17RB. Am J Respir Crit Care Med (2013) 187(8):812-22. doi:10.1164/rccm.201211-2073OC

76. Li B, Reynolds JM, Stout RD, Bernlohr DA, Suttles J. Regulation of Th17 differentiation by epidermal fatty acid-binding protein. J Immunol (2009) 182(12):7625-33. doi:10.4049/jimmunol.0804192

77. Kaul V, Van Kaer L, Das G, Das J. Prostanoid receptor 2 signaling protects T helper 2 cells from BALB/c mice against activation-induced cell death. J Biol Chem (2012) 287(30):25434-9. doi:10.1074/jbc.C111.324707

78. Khayrullina T, Yen JH, Jing H, Ganea D. In vitro differentiation of dendritic cells in the presence of prostaglandin E2 alters the IL-12/IL-23 balance and promotes differentiation of Th17 cells. J Immunol (2008) 181(1):721-35.

79. Miles EA, Aston L, Calder PC. In vitro effects of eicosanoids derived from different 20-carbon fatty acids on T helper type 1 and $\mathrm{T}$ helper type 2 cytokine production in human whole-blood cultures. Clin Exp Allergy (2003) 33(5):624-32. doi:10.1046/j.1365-2222.2003.01637.x

80. Napolitani G, Acosta-Rodriguez EV, Lanzavecchia A, Sallusto F. Prostaglandin E2 enhances Th17 responses via modulation of IL-17 and IFN-gamma production by memory CD4+ T cells. Eur J Immunol (2009) 39(5):1301-12. doi:10.1002/eji.200838969

81. Sreeramkumar V, Fresno M, Cuesta N. Prostaglandin E2 and T cells: friends or foes? Immunol Cell Biol (2012) 90(6):579-86. doi:10.1038/icb.2011.75

82. Rana S, Byrne SN, MacDonald LJ, Chan CY, Halliday GM. Ultraviolet B suppresses immunity by inhibiting effector and memory T cells. Am J Pathol (2008) 172(4):993-1004. doi:10.2353/ajpath.2008.070517

83. Krause P, Bruckner M, Uermosi C, Singer E, Groettrup M, Legler DF. Prostaglandin $\mathrm{E}(2)$ enhances T-cell proliferation by inducing the costimulatory molecules OX40L, CD70, and 4-1BBL on dendritic cells. Blood (2009) 113(11):2451-60. doi:10.1182/blood-2008-05-157123 
84. Muthuswamy R, Mueller-Berghaus J, Haberkorn U, Reinhart TA, Schadendorf D, Kalinski P. PPGE(2) transiently enhances DC expression of CCR7 but inhibits the ability of DCs to produce CCL19 and attract naive T cells. Blood (2010) 116(9):1454-9. doi:10.1182/blood-2009-12-258038

85. Shimabukuro-Vornhagen A, Liebig TM, Koslowsky T, Theurich S, von Bergwelt-Baildon MS. The ratio between dendritic cells and T cells determines whether prostaglandin E2 has a stimulatory or inhibitory effect. Cell Immunol (2013) 281(1):62-7. doi:10.1016/j.cellimm.2013.01.001

86. Mrabet-Dahbi S, Maurer M. Does allergy impair innate immunity? Leads and lessons from atopic dermatitis. Allergy (2011) 65(11):1351-6. doi:10.1111/j. 1398-9995.2010.02452.x

87. Deckers J, Branco Madeira F, Hammad H. Innate immune cells in asthma. Trends Immunol (2013) 34(11):540-7. doi:10.1016/j.it.2013.08.004

88. Nagamachi M, Sakata D, Kabashima K, Furuyashiki T, Murata T, Segi-Nishida E, et al. Facilitation of Th1-mediated immune response by prostaglandin E receptor EP1. J Exp Med (2007) 204(12):2865-74. doi:10.1084/jem.20070773

89. Esaki Y, Li Y, Sakata D, Yao C, Segi-Nishida E, Matsuoka T, et al. Dual roles of PGE2-EP4 signaling in mouse experimental autoimmune encephalomyelitis. Proc Natl Acad Sci U S A (2010) 107(27):12233-8. doi:10.1073/pnas. 0915112107

90. Yao C, Sakata D, Esaki Y, Li Y, Matsuoka T, Kuroiwa K, et al. Prostaglandin E2-EP4 signaling promotes immune inflammation through Th1 cell differentiation and Th17 cell expansion. Nat Med (2009) 15(6):633-40. doi:10.1038/ nm.1968

91. Valitutti S, Dessing M, Lanzavecchia A. Role of cAMP in regulating cytotoxic T lymphocyte adhesion and motility. Eur J Immunol (1993) 23(4):790-5. doi:10.1002/eji.1830230403

92. Santoli D, Zurier RB. Prostaglandin E precursor fatty acids inhibit human IL-2 production by a prostaglandin E-independent mechanism. J Immunol (1989) 143(4):1303-9.

93. Van Epps DE. Suppression of human lymphocyte migration by PGE2. Inflammation (1981) 5(1):81-7. doi:10.1007/BF00910782

94. Koga Y, Tanaka K, Yokoyama M, Taniguchi K, Nomoto K. Thymus cell migration in a prostaglandin-mediated system. Immunobiology (1985) 169(5):486-502. doi:10.1016/S0171-2985(85)80004-8

95. Wiemer AJ, Hegde S, Gumperz JE, Huttenlocher A. A live imaging cell motility screen identifies prostaglandin E2 as a T cell stop signal antagonist. J Immunol (2011) 187(7):3663-70. doi:10.4049/jimmunol.1100103

96. Jordan ML, Hoffman RA, Debe EF, Simmons RL. In vitro locomotion of allosensitized $\mathrm{T}$ lymphocyte clones in response to metabolites of arachidonic acid is subset specific. J Immunol (1986) 137(2):661-8.

97. Jordan ML, Hoffman RA, Debe EF, West MA, Simmons RL. Prostaglandin E2 mediates subset-specific effects on the functional responses of allosensitized T lymphocyte clones. Transplantation (1987) 43(1):117-23. doi:10.1097/ 00007890-198701000-00026

98. Jordan ML, Vidgen DF, Wright J, Odell M, Mills GB. Sustained increases in cytosolic calcium during $\mathrm{T}$ lymphocyte allosensitization, proliferation, and acquisition of locomotor function. Transplantation (1991) 51(2):464-8.

99. Oppenheimer-Marks N, Kavanaugh AF, Lipsky PE. Inhibition of the transendothelial migration of human $\mathrm{T}$ lymphocytes by prostaglandin E2. J Immunol (1994) 152(12):5703-13.

100. Mesri M, Liversidge J, Forrester JV. Prostaglandin E2 and monoclonal antibody to lymphocyte function-associated antigen-1 differentially inhibit migration of T lymphocytes across microvascular retinal endothelial cells in rat. Immunology (1996) 88(3):471-7. doi:10.1046/j.1365-2567.1996.d01-671.x

101. Leppert D, Hauser SL, Kishiyama JL, An S, Zeng L, Goetzl EJ. Stimulation of matrix metalloproteinase-dependent migration of $\mathrm{T}$ cells by eicosanoids. FASEB J (1995) 9(14):1473-81.

102. Karavitis J, Hix LM, Shi YH, Schultz RF, Khazaie K, Zhang M. Regulation of COX2 expression in mouse mammary tumor cells controls bone metastasis and PGE2-induction of regulatory T cell migration. PLoS One (2012) 7(9):e46342. doi:10.1371/journal.pone.0046342

103. Harris SG, Padilla J, Koumas L, Ray D, Phipps RP. Prostaglandins as modulators of immunity. Trends Immunol (2002) 23(3):144-50. doi:10.1016/S14714906(01)02154-8

104. Tanaka K, Ogawa K, Sugamura K, Nakamura M, Takano S, Nagata K. Cutting edge: differential production of prostaglandin $\mathrm{D} 2$ by human helper $\mathrm{T}$ cell subsets. J Immunol (2000) 164(5):2277-80.
105. Mutalithas K, Guillen C, Day C, Brightling CE, Pavord ID, Wardlaw AJ. CRTH2 expression on T cells in asthma. Clin Exp Immunol (2010) 161(1):34-40. doi:10.1111/j.1365-2249.2010.04161.x

106. Tanaka K, Hirai H, Takano S, Nakamura M, Nagata K. Effects of prostaglandin D2 on helper $\mathrm{T}$ cell functions. Biochem Biophys Res Commun (2004) 316(4):1009-14. doi:10.1016/j.bbrc.2004.02.151

107. Hirai H, Tanaka K, Yoshie O, Ogawa K, Kenmotsu K, Takamori Y, et al. Prostaglandin D2 selectively induces chemotaxis in T helper type 2 cells, eosinophils, and basophils via seven-transmembrane receptor CRTH2. J Exp Med (2001) 193(2):255-61. doi:10.1084/jem.193.2.255

108. Schuligoi R, Sedej M, Waldhoer M, Vukoja A, Sturm EM, Lippe IT, et al. Prostaglandin $\mathrm{H} 2$ induces the migration of human eosinophils through the chemoattractant receptor homologous molecule of Th2 cells, CRTH2. J Leukoc Biol (2009) 85(1):136-45. doi:10.1189/jlb.0608387

109. Pettipher $\mathrm{R}$. The roles of the prostaglandin $\mathrm{D}(2)$ receptors $\mathrm{DP}(1)$ and CRTH2 in promoting allergic responses. Br J Pharmacol (2008) 153(Suppl 1):S191-9. doi:10.1038/sj.bjp.0707488

110. Yamamoto Y, Otani S, Hirai H, Nagata K, Aritake K, Urade Y, et al. Dual functions of prostaglandin D2 in murine contact hypersensitivity via DP and CRTH2. Am J Pathol (2011) 179(1):302-14. doi:10.1016/j.ajpath.2011. 03.047

111. Raman P, Kaplan BL, Kaminski NE. 15-Deoxy-Delta(1)(2),(1)(4)prostaglandin $\mathrm{J}(2)$-glycerol, a putative metabolite of 2-arachidonoyl glycerol and a peroxisome proliferator-activated receptor gamma ligand, modulates nuclear factor of activated T cells. J Pharmacol Exp Ther (2013) 342(3):816-26. doi:10.1124/jpet.112.193003

112. Sykes L, MacIntyre DA, Yap XJ, Ponnampalam S, Teoh TG, Bennett PR. Changes in the Th1:Th2 cytokine bias in pregnancy and the effects of the anti-inflammatory cyclopentenone prostaglandin 15-deoxy-Delta(12,14)prostaglandin J2. Mediators Inflamm (2012) 2012:416739. doi:10.1155/2012/ 416739

113. Perez-Novo CA, Holtappels G, Vinall SL, Xue L, Zhang N, Bachert C, et al. CRTH2 mediates the activation of human Th2 cells in response to $\mathrm{PGD}(2)$ released from IgE/anti-IgE treated nasal polyp tissue. Allergy (2009) 65(3):304-10. doi:10.1111/j.1398-9995.2009.02204.x

114. Xue L, Gyles SL, Barrow A, Pettipher R. Inhibition of PI3K and calcineurin suppresses chemoattractant receptor-homologous molecule expressed on Th2 cells (CRTH2)-dependent responses of Th2 lymphocytes to prostaglandin $\mathrm{D}(2)$. Biochem Pharmacol (2007) 73(6):843-53. doi:10.1016/j.bcp.2006.11.021

115. Xue L, Barrow A, Pettipher R. Interaction between prostaglandin D and chemoattractant receptor-homologous molecule expressed on Th2 cells mediates cytokine production by Th2 lymphocytes in response to activated mast cells. Clin Exp Immunol (2009) 156(1):126-33. doi:10.1111/j.1365-2249.2008. 03871.x

116. Vinall SL, Townsend ER, Pettipher R. A paracrine role for chemoattractant receptor-homologous molecule expressed on T helper type 2 cells (CRTH2) in mediating chemotactic activation of CRTH2+ CD4+ T helper type 2 lymphocytes. Immunology (2007) 121(4):577-84. doi:10.1111/j.1365-2567.2007. 02606.x

117. Ahmed SR, McGettrick HM, Yates CM, Buckley CD, Ratcliffe MJ, Nash GB, et al. Prostaglandin D2 regulates CD4+ memory $\mathrm{T}$ cell trafficking across blood vascular endothelium and primes these cells for clearance across lymphatic endothelium. J Immunol (2011) 187(3):1432-9. doi:10.4049/jimmunol. 1100299

118. Shirasaki H, Kikuchi M, Kanaizumi E, Himi T. Accumulation of CRTH2positive leukocytes in human allergic nasal mucosa. Ann Allergy Asthma Immunol (2009) 102(2):110-5. doi:10.1016/S1081-1206(10)60239-6

119. Gyles SL, Xue L, Townsend ER, Wettey F, Pettipher R. A dominant role for chemoattractant receptor-homologous molecule expressed on T helper type 2 (Th2) cells (CRTH2) in mediating chemotaxis of CRTH2+ CD4+ Th2 lymphocytes in response to mast cell supernatants. Immunology (2006) 119(3):362-8. doi:10.1111/j.1365-2567.2006.02440.x

120. Gosset P, Bureau F, Angeli V, Pichavant M, Faveeuw C, Tonnel AB, et al. Prostaglandin D2 affects the maturation of human monocyte-derived dendritic cells: consequence on the polarization of naive Th cells. J Immunol (2003) 170(10):4943-52.

121. Gosset P, Pichavant M, Faveeuw C, Bureau F, Tonnel AB, Trottein F. Prostaglandin D2 affects the differentiation and functions of human dendritic 
cells: impact on the T cell response. Eur J Immunol (2005) 35(5):1491-500. doi:10.1002/eji.200425319

122. Zhao J, Legge K, Perlman S. Age-related increases in PGD(2) expression impair respiratory DC migration, resulting in diminished $\mathrm{T}$ cell responses upon respiratory virus infection in mice. J Clin Invest (2011) 121(12):4921-30. doi:10.1172/JCI59777

123. Li H, Bradbury JA, Dackor RT, Edin ML, Graves JP, DeGraff LM, et al. Cyclooxygenase-2 regulates Th17 cell differentiation during allergic lung inflammation. Am J Respir Crit Care Med (2011) 184(1):37-49. doi:10.1164/ rccm.201010-1637OC

124. Zhou W, Hashimoto K, Goleniewska K, O’Neal JF, Ji S, Blackwell TS, et al. Prostaglandin $\mathrm{I} 2$ analogs inhibit proinflammatory cytokine production and $\mathrm{T}$ cell stimulatory function of dendritic cells. J Immunol (2007) 178(2):702-10.

125. Nakajima S, Honda T, Sakata D, Egawa G, Tanizaki H, Otsuka A, et al. Prostaglandin I2-IP signaling promotes Th1 differentiation in a mouse model of contact hypersensitivity. J Immunol (2010) 184(10):5595-603. doi:10.4049/ jimmunol.0903260

126. Wu KK, Papp AC, Manner CE, Hall ER. Interaction between lymphocytes and platelets in the synthesis of prostacyclin. J Clin Invest (1987) 79(6):1601-6. doi:10.1172/JCI112995

127. Liu W, Li H, Zhang X, Wen D, Yu F, Yang S, et al. Prostaglandin I2-IP signalling regulates human Th17 and Treg cell differentiation. Prostaglandins Leukot Essent Fatty Acids (2013) 89(5):335-44. doi:10.1016/j.plefa.2013.08.006

128. Jaffar Z, Ferrini ME, Buford MC, Fitzgerald GA, Roberts K. Prostaglandin I2-IP signaling blocks allergic pulmonary inflammation by preventing recruitment of $\mathrm{CD} 4+\mathrm{Th} 2$ cells into the airways in a mouse model of asthma. J Immunol (2007) 179(9):6193-203.

129. Zhou W, Dowell DR, Huckabee MM, Newcomb DC, Boswell MG, Goleniewska $\mathrm{K}$, et al. Prostaglandin I2 signaling drives Th17 differentiation and exacerbates experimental autoimmune encephalomyelitis. PLoS One (2012) 7(5):e33518. doi:10.1371/journal.pone.0033518

130. Kabashima K, Murata T, Tanaka H, Matsuoka T, Sakata D, Yoshida N, et al. Thromboxane A2 modulates interaction of dendritic cells and $\mathrm{T}$ cells and regulates acquired immunity. Nat Immunol (2003) 4(7):694-701. doi:10.1038/ ni943

131. Thomas DW, Rocha PN, Nataraj C, Robinson LA, Spurney RF, Koller BH, et al. Proinflammatory actions of thromboxane receptors to enhance cellular immune responses. J Immunol (2003) 171(12):6389-95.

132. Ushikubi F, Aiba Y, Nakamura K, Namba T, Hirata M, Mazda O, et al. Thromboxane A2 receptor is highly expressed in mouse immature thymocytes and mediates DNA fragmentation and apoptosis. J Exp Med (1993) 178(5):1825-30. doi:10.1084/jem.178.5.1825

133. Kohyama K, Hashimoto M, Abe S, Kodaira K, Yukawa T, Hozawa S, et al. Thromboxane A2 receptor $+795 \mathrm{~T}>\mathrm{C}$ and chemoattractant receptorhomologous molecule expressed on Th2 cells $-466 \mathrm{~T}>\mathrm{C}$ gene polymorphisms in patients with aspirin-exacerbated respiratory disease. Mol Med Rep (2012) 5(2):477-82. doi:10.3892/mmr.2011.680

134. Kumar GS, Das UN. Effect of prostaglandins and their precursors on the proliferation of human lymphocytes and their secretion of tumor necrosis factor and various interleukins. Prostaglandins Leukot Essent Fatty Acids (1994) 50(6):331-4. doi:10.1016/0952-3278(94)90242-9

135. Cook-Moreau JM, El-Makhour Hojeij Y, Barriere G, Rabinovitch-Chable HC, Faucher KS, Sturtz FG, et al. Expression of 5-lipoxygenase (5-LOX) in T lymphocytes. Immunology (2007) 122(2):157-66. doi:10.1111/j.1365-2567.2007. 02621.x

136. Cai Y, Kumar RK, Zhou J, Foster PS, Webb DC. Ym1/2 promotes Th2 cytokine expression by inhibiting 12/15(S)-lipoxygenase: identification of a novel pathway for regulating allergic inflammation. J Immunol (2009) 182(9):5393-9. doi:10.4049/jimmunol.0803874

137. Kato K, Koshihara Y, Fujiwara M, Murota S. Augmentation of 12-lipoxygenase activity of lymph node and spleen T cells in autoimmune mice MRL/1. Prostaglandins Leukot Med (1983) 12(3):273-80. doi:10.1016/0262-1746(83) 90005-7

138. el Makhour-Hojeij Y, Baclet MC, Chable-Rabinovitch H, Beneytout JL, Cook J. Expression of 5-lipoxygenase in lymphoblastoid B and T cells. Prostaglandins (1994) 48(1):21-9. doi:10.1016/0090-6980(94)90093-0

139. Atluru D, Lianos EA, Goodwin JS. Arachidonic acid inhibits 5-lipoxygenase in human T cells. Biochem Biophys Res Commun (1986) 135(2):670-6. doi:10.1016/0006-291X(86)90045-8
140. Goodarzi K, Goodarzi M, Tager AM, Luster AD, von Andrian UH. Leukotriene B4 and BLT1 control cytotoxic effector T cell recruitment to inflamed tissues. Nat Immunol (2003) 4(10):965-73. doi:10.1038/ni972

141. Tager AM, Bromley SK, Medoff BD, Islam SA, Bercury SD, Friedrich EB, et al. Leukotriene B4 receptor BLT1 mediates early effector T cell recruitment. Nat Immunol (2003) 4(10):982-90. doi:10.1038/ni970

142. Costa MF, de Souza-Martins R, de Souza MC, Benjamim CF, Piva B, Diaz $\mathrm{BL}$, et al. Leukotriene B4 mediates gammadelta $\mathrm{T}$ lymphocyte migration in response to diverse stimuli. J Leukoc Biol (2010) 87(2):323-32. doi:10.1189/jlb. 0809563

143. Medeiros AI, Sa-Nunes A, Turato WM, Secatto A, Frantz FG, Sorgi CA, et al. Leukotrienes are potent adjuvant during fungal infection: effects on memory T cells. J Immunol (2008) 181(12):8544-51.

144. Luster AD, Tager AM. T-cell trafficking in asthma: lipid mediators grease the way. Nat Rev Immunol (2004) 4(9):711-24. doi:10.1038/nri1438

145. Nancey S, Boschetti G, Hacini F, Sardi F, Durand PY, Le Borgne M, et al. Blockade of LTB(4)/BLT(1) pathway improves CD8(+) T-cell-mediated colitis. Inflamm Bowel Dis (2011) 17(1):279-88. doi:10.1002/ibd.21404

146. Chen H, Qin J, Wei P, Zhang J, Li Q, Fu L, et al. Effects of leukotriene B4 and prostaglandin E2 on the differentiation of murine Foxp3+ T regulatory cells and Th17 cells. Prostaglandins Leukot Essent Fatty Acids (2009) 80(4):195-200. doi:10.1016/j.plefa.2009.01.006

147. DiMeo D, Tian J, Zhang J, Narushima S, Berg DJ. Increased interleukin-10 production and Th2 skewing in the absence of 5-lipoxygenase. Immunology (2007) 123(2):250-62. doi:10.1111/j.1365-2567.2007.02694.x

148. Arcoleo F, Milano S, D'Agostino P, Cillari E. Effect of exogenous leukotriene B4 (LTB4) on BALB/c mice splenocyte production of Th1 and Th2 lymphokines. Int J Immunopharmacol (1995) 17(6):457-63. doi:10.1016/01920561(95)00038-4

149. Dornand J, Gerber M. Mechanisms of IL2 production impairment by lipoxygenase inhibitors in activated Jurkat cells. J Lipid Mediat (1991) 4(1):23-38.

150. Laidlaw TM, Boyce JA. Cysteinyl leukotriene receptors, old and new; implications for asthma. Clin Exp Allergy (2013) 42(9):1313-20. doi:10.1111/j.13652222.2012.03982.x

151. Parmentier CN, Fuerst E, McDonald J, Bowen H, Lee TH, Pease JE, et al. Human $\mathrm{T}(\mathrm{H}) 2$ cells respond to cysteinyl leukotrienes through selective expression of cysteinyl leukotriene receptor 1. JAllergy Clin Immunol (2012) 129(4):1136-42. doi:10.1016/j.jaci.2012.01.057

152. Prinz I, Gregoire C, Mollenkopf H, Aguado E, Wang Y, Malissen M, et al. The type 1 cysteinyl leukotriene receptor triggers calcium influx and chemotaxis in mouse alpha beta- and gamma delta effector T cells. J Immunol (2005) 175(2):713-9.

153. Xue L, Barrow A, Fleming VM, Hunter MG, Ogg G, Klenerman P, et al. Leukotriene E4 activates human Th2 cells for exaggerated proinflammatory cytokine production in response to prostaglandin D2. J Immunol (2011) 188(2):694-702. doi:10.4049/jimmunol.1102474

154. Bailey JM, Vanderhoek JY, Makheja AN, Pupillo M. Activation of mitogeninduced T-lymphocyte proliferation by leukotriene C-4. Biochem Soc Trans (1997) 25(3):503S

155. Dannull J, Schneider T, Lee WT, de Rosa N, Tyler DS, Pruitt SK. Leukotriene C4 induces migration of human monocyte-derived dendritic cells without loss of immunostimulatory function. Blood (2012) 119(13):3113-22. doi:10.1182/blood-2011-10-385930

156. Zhang Y, Styhler A, Powell WS. Synthesis of 5-oxo-6,8,11,14-eicosatetraenoic acid by human monocytes and lymphocytes. J Leukoc Biol (1996) 59(6): $847-54$.

157. Erlemann KR, Rokach J, Powell WS. Oxidative stress stimulates the synthesis of the eosinophil chemoattractant 5-oxo-6,8,11,14-eicosatetraenoic acid by inflammatory cells. J Biol Chem (2004) 279(39):40376-84. doi:10.1074/jbc. M401294200

158. Bacon KB, Camp RD. Lipid lymphocyte chemoattractants in psoriasis. Prostaglandins (1990) 40(6):603-14. doi:10.1016/0090-6980(90)90005-G

159. Bacon KB, Camp RD, Cunningham FM, Woollard PM. Contrasting in vitro lymphocyte chemotactic activity of the hydroxyl enantiomers of 12-hydroxy5,8,10,14-eicosatetraenoic acid. Br J Pharmacol (1988) 95(3):966-74. doi:10. 1111/j.1476-5381.1988.tb11727.x

160. Kumar KA, Arunasree KM, Roy KR, Reddy NP, Aparna A, Reddy GV, et al. Effects of (15S)-hydroperoxyeicosatetraenoic acid and (15S)hydroxyeicosatetraenoic acid on the acute- lymphoblastic-leukaemia cell line 
Jurkat: activation of the Fas-mediated death pathway. Biotechnol Appl Biochem (2009) 52(Pt 2):121-33. doi:10.1042/BA20070264

161. Bailey JM, Bryant RW, Low CE, Pupillo MB, Vanderhoek JY. Regulation of T-lymphocyte mitogenesis by the leukocyte product 15-hydroxyeicosatetraenoic acid (15-HETE). Cell Immunol (1982) 67(1):112-20. doi:10. 1016/0008-8749(82)90203-9

162. Bailey JM, Fletcher M, Vanderhoek JY, Makheja AN. Regulation of human T-lymphocyte proliferative responses by the lipoxygenase product 15-HETE. Biochem Soc Trans (1997) 25(2):247S.

163. Hadjiagapiou C, Travers JB, Fertel RH, Sprecher H. Metabolism of 15-hydroxy5,8,11,13-eicosatetraenoic acid by MOLT- 4 cells and blood T-lymphocytes. J Biol Chem (1990) 265(8):4369-73.

164. Jeon SG, Moon HG, Kim YS, Choi JP, Shin TS, Hong SW, et al. 15-Lipoxygenase metabolites play an important role in the development of a T-helper type 1 allergic inflammation induced by double-stranded RNA. Clin Exp Allergy (2009) 39(6):908-17. doi:10.1111/j.1365-2222.2009.03211.x

165. Lin KT, Godfrey HP, Spokas EG, Sun FF, Wong PY. Modulation of LTB4 receptor in T-lymphocytes by lipoxin A4 (LXA4) and its role in delayed-type hypersensitivity. Adv Exp Med Biol (1999) 447:151-63. doi:10.1007/978-1-4615-48614_14

166. Lin KT, Dudhane A, Godfrey HP, Wong PY. Identification and characterization of a high-affinity leukotriene B4 receptor on guinea pig T lymphocytes and its regulation by lipoxin A4. J Pharmacol Exp Ther (1996) 277(2):679-84.

167. Ariel A, Chiang N, Arita M, Petasis NA, Serhan CN. Aspirin-triggered lipoxin A4 and B4 analogs block extracellular signal-regulated kinase-dependent TNFalpha secretion from human T cells. J Immunol (2003) 170(12):6266-72.

168. Zhang B, Jia H, Liu J, Yang Z, Jiang T, Tang K, et al. Depletion of regulatory T cells facilitates growth of established tumors: a mechanism involving the regulation of myeloid-derived suppressor cells by lipoxin A4. J Immunol (2010) 185(12):7199-206. doi:10.4049/jimmunol.1001876

169. Ariel A, Li PL, Wang W, Tang WX, Fredman G, Hong S, et al. The docosatriene protectin D1 is produced by $\mathrm{TH} 2$ skewing and promotes human $\mathrm{T}$ cell apoptosis via lipid raft clustering. J Biol Chem (2005) 280(52):43079-86. doi:10.1074/jbc.M509796200

170. Kim TH, Kim GD, Jin YH, Park YS, Park CS. Omega-3 fatty acid-derived mediator, resolvin E1, ameliorates 2,4-dinitrofluorobenzene-induced atopic dermatitis in NC/Nga mice. Int Immunopharmacol (2012) 14(4):384-91. doi:10.1016/j.intimp.2012.08.005

171. Vassiliou EK, Kesler OM, Tadros JH, Ganea D. Bone marrow-derived dendritic cells generated in the presence of resolvin E1 induce apoptosis of activated CD4+ T cells. J Immunol (2008) 181(7):4534-44.

172. Rajasagi NK, Reddy PB, Suryawanshi A, Mulik S, Gjorstrup P, Rouse BT. Controlling herpes simplex virus-induced ocular inflammatory lesions with the lipid-derived mediator resolvin E1. J Immunol (2011) 186(3):1735-46. doi:10.4049/jimmunol.1003456

173. Bambang KN, Lambert DG, Lam PM, Quenby S, Maccarrone M, Konje JC. Immunity and early pregnancy events: are endocannabinoids the missing link? J Reprod Immunol (2012) 96(1-2):8-18. doi:10.1016/j.jri.2012.10.003

174. Maccarrone M, Bari M, Battista N, Finazzi-Agro A. Endocannabinoid degradation, endotoxic shock and inflammation. Curr Drug Targets Inflamm Allergy (2002) 1(1):53-63. doi:10.2174/1568010023344878

175. Nagarkatti P, Pandey R, Rieder SA, Hegde VL, Nagarkatti M. Cannabinoids as novel anti-inflammatory drugs. Future Med Chem (2009) 1(7):1333-49. doi: $10.4155 /$ fmc.09.93

176. Rieder SA, Chauhan A, Singh U, Nagarkatti M, Nagarkatti P. Cannabinoidinduced apoptosis in immune cells as a pathway to immunosuppression. Immunobiology (2009) 215(8):598-605. doi:10.1016/j.imbio.2009.04.001

177. Maccarrone M, De Petrocellis L, Bari M, Fezza F, Salvati S, Di Marzo V, et al. Lipopolysaccharide downregulates fatty acid amide hydrolase expression and increases anandamide levels in human peripheral lymphocytes. Arch Biochem Biophys (2001) 393(2):321-8. doi:10.1006/abbi.2001.2500

178. Maccarrone M, Bari M, Di Rienzo M, Finazzi-Agro A, Rossi A. Progesterone activates fatty acid amide hydrolase (FAAH) promoter in human T lymphocytes through the transcription factor Ikaros. Evidence for a synergistic effect of leptin. J Biol Chem (2003) 278(35):32726-32. doi:10.1074/jbc.M302123200

179. Coopman K, Smith LD, Wright KL, Ward SG. Temporal variation in CB2R levels following $\mathrm{T}$ lymphocyte activation: evidence that cannabinoids modulate CXCL12-induced chemotaxis. Int Immunopharmacol (2007) 7(3):360-71. doi:10.1016/j.intimp.2006.11.008
180. Daaka Y, Friedman H, Klein TW. Cannabinoid receptor proteins are increased in Jurkat, human T-cell line after mitogen activation. J Pharmacol Exp Ther (1996) 276(2):776-83.

181. Robinson RH, Meissler JJ, Breslow-Deckman JM, Gaughan J, Adler MW, Eisenstein TK. Cannabinoids inhibit T-cells via cannabinoid receptor 2 in an in vitro assay for graft rejection, the mixed lymphocyte reaction. J Neuroimmune Pharmacol (2013) 8(5):1239-50. doi:10.1007/s11481-013-9485-1

182. Ziring D, Wei B, Velazquez P, Schrage M, Buckley NE, Braun J. Formation of $\mathrm{B}$ and $\mathrm{T}$ cell subsets require the cannabinoid receptor $\mathrm{CB} 2$. Immunogenetics (2006) 58(9):714-25. doi:10.1007/s00251-006-0138-x

183. Sipe JC, Arbour N, Gerber A, Beutler E. Reduced endocannabinoid immune modulation by a common cannabinoid 2 (CB2) receptor gene polymorphism: possible risk for autoimmune disorders. J Leukoc Biol (2005) 78(1):231-8. doi:10.1189/jlb.0205111

184. Hegde VL, Hegde S, Cravatt BF, Hofseth LJ, Nagarkatti M, Nagarkatti PS. Attenuation of experimental autoimmune hepatitis by exogenous and endogenous cannabinoids: involvement of regulatory T cells. Mol Pharmacol (2008) 74(1):20-33. doi:10.1124/mol.108.047035

185. Eisenstein TK, Meissler JJ, Wilson Q, Gaughan JP, Adler MW. Anandamide and Delta9-tetrahydrocannabinol directly inhibit cells of the immune system via CB2 receptors. J Neuroimmunol (2007) 189(1-2):17-22. doi:10.1016/ j.jneuroim.2007.06.001

186. Cencioni MT, Chiurchiu V, Catanzaro G, Borsellino G, Bernardi G, Battistini L, et al. Anandamide suppresses proliferation and cytokine release from primary human T-lymphocytes mainly via CB2 receptors. PLoS One (2010) 5(1):e8688. doi:10.1371/journal.pone.0008688

187. Schwarz H, Blanco FJ, Lotz M. Anadamide, an endogenous cannabinoid receptor agonist inhibits lymphocyte proliferation and induces apoptosis. $\mathrm{J} \mathrm{Neu-}$ roimmunol (1994) 55(1):107-15. doi:10.1016/0165-5728(94)90152-X

188. Sarker KP, Maruyama I. Anandamide induces cell death independently of cannabinoid receptors or vanilloid receptor 1: possible involvement of lipid rafts. Cell Mol Life Sci (2003) 60(6):1200-8.

189. Joseph J, Niggemann B, Zaenker KS, Entschladen F. Anandamide is an endogenous inhibitor for the migration of tumor cells and T lymphocytes. Cancer Immunol Immunother (2004) 53(8):723-8. doi:10.1007/s00262-004-0509-9

190. Lissoni P, Tintori A, Fumagalli L, Brivio F, Messina G, Parolini D, et al. The endocannabinoid anandamide neither impairs in vitro T-cell function nor induces regulatory T-cell generation. Anticancer Res (2008) 28(6A): 3743-8.

191. Lenglet S, Thomas A, Soehnlein O, Montecucco F, Burger F, Pelli G, et al. Fatty acid amide hydrolase deficiency enhances intraplaque neutrophil recruitment in atherosclerotic mice. Arterioscler Thromb Vasc Biol (2013) 33(2):215-23. doi:10.1161/ATVBAHA.112.300275

192. Ribeiro A, Ferraz-de-Paula V, Pinheiro ML, Sakai M, Costa-Pinto FA, PalermoNeto J. Anandamide prior to sensitization increases cell-mediated immunity in mice. Int Immunopharmacol (2010) 10(4):431-9. doi:10.1016/j.intimp.2009. 12.017

193. Chen J, Lu RT, Lai R, Dinh T, Paul D, Venadas S, et al. Bimatoprost-induced calcium signaling in human T-cells does not involve prostanoid FP or TP receptors. Curr Eye Res (2009) 34(3):184-95. doi:10.1080/02713680802669781

194. Jorda MA, Verbakel SE, Valk PJ, Vankan-Berkhoudt YV, Maccarrone M, FinazziAgro A, et al. Hematopoietic cells expressing the peripheral cannabinoid receptor migrate in response to the endocannabinoid 2-arachidonoylglycerol. Blood (2002) 99(8):2786-93. doi:10.1182/blood.V99.8.2786

195. Basu S, Ray A, Dittel BN. Cannabinoid receptor 2 is critical for the homing and retention of marginal zone B lineage cells and for efficient T-independent immune responses. J Immunol (2011) 187(11):5720-32. doi: 10.4049/jimmunol.1102195

196. Kishimoto S, Muramatsu M, Gokoh M, Oka S, Waku K, Sugiura T. Endogenous cannabinoid receptor ligand induces the migration of human natural killer cells. J Biochem (2005) 137(2):217-23. doi:10.1093/jb/mvi021

197. Maestroni GJ. The endogenous cannabinoid 2-arachidonoyl glycerol as in vivo chemoattractant for dendritic cells and adjuvant for Th1 response to a soluble protein. FASEB J (2004) 18(15):1914-6. doi:10.1096/fj.04-2190fje

198. Rockwell CE, Snider NT, Thompson JT, Vanden Heuvel JP, Kaminski NE. Interleukin-2 suppression by 2-arachidonoyl glycerol is mediated through peroxisome proliferator-activated receptor gamma independently of cannabinoid receptors 1 and 2. Mol Pharmacol (2006) 70(1):101-11. doi:10.1124/mol.105. 019117 
199. Rockwell CE, Raman P, Kaplan BL, Kaminski NE. A COX-2 metabolite of the endogenous cannabinoid, 2-arachidonoyl glycerol, mediates suppression of IL2 secretion in activated Jurkat T cells. Biochem Pharmacol (2008) 76(3):353-61. doi:10.1016/j.bcp.2008.05.005

200. McCusker MM, Grant-Kels JM. Healing fats of the skin: the structural and immunologic roles of the omega- 6 and omega-3 fatty acids. Clin Dermatol (2010) 28(4):440-51. doi:10.1016/j.clindermatol.2010.03.020

201. Woodworth HL, McCaskey SJ, Duriancik DM, Clinthorne JF, Langohr IM, Gardner EM, et al. Dietary fish oil alters T lymphocyte cell populations and exacerbates disease in a mouse model of inflammatory colitis. Cancer Res (2011) 70(20):7960-9. doi:10.1158/0008-5472.CAN-10-1396

202. Monk JM, Jia Q, Callaway E, Weeks B, Alaniz RC, McMurray DN, et al. Th17 cell accumulation is decreased during chronic experimental colitis by (n-3) PUFA in Fat-1 mice. J Nutr (2011) 142(1):117-24. doi:10.3945/jn.111. 147058

203. Vassilopoulos D, Zurier RB, Rossetti RG, Tsokos GC. Gammalinolenic acid and dihomogammalinolenic acid suppress the CD3-mediated signal transduction pathway in human T cells. Clin Immunol Immunopathol (1997) 83(3):237-44. doi:10.1006/clin.1997.4343

204. Kim W, Khan NA, McMurray DN, Prior IA, Wang N, Chapkin RS. Regulatory activity of polyunsaturated fatty acids in T-cell signaling. Prog Lipid Res (2010) 49(3):250-61. doi:10.1016/j.plipres.2010.01.002

205. Bassaganya-Riera J, Hontecillas R. Dietary conjugated linoleic acid and n-3 polyunsaturated fatty acids in inflammatory bowel disease. Curr Opin Clin Nutr Metab Care (2010) 13(5):569-73. doi:10.1097/MCO.0b013e32833b648e

206. Cao S, Ren J, Sun L, Gu G, Yuan Y, Li J. Fish oil-supplemented parenteral nutrition prolongs survival while beneficially altering phospholipids' fatty acid composition and modulating immune function in rat sepsis. Shock (2011) 36(2):184-90. doi:10.1097/SHK.0b013e31821e4f8b

207. Cawood AL, Ding R, Napper FL, Young RH, Williams JA, Ward MJ, et al. Eicosapentaenoic acid (EPA) from highly concentrated n-3 fatty acid ethyl esters is incorporated into advanced atherosclerotic plaques and higher plaque EPA is associated with decreased plaque inflammation and increased stability. Atherosclerosis (2010) 212(1):252-9. doi:10.1016/j.atherosclerosis. 2010.05.022

208. Chen EP, Smyth EM. COX-2 and PGE2-dependent immunomodulation in breast cancer. Prostaglandins Other Lipid Mediat (2011) 96(1-4):14-20. doi:10.1016/j.prostaglandins.2011.08.005

209. Ott J, Hiesgen C, Mayer K. Lipids in critical care medicine. Prostaglandins Leukot Essent Fatty Acids (2011) 85(5):267-73. doi:10.1016/j.plefa.2011.04.011
210. Suzuki D, Furukawa K, Kimura F, Shimizu H, Yoshidome H, Ohtsuka M, et al. Effects of perioperative immunonutrition on cell-mediated immunity, Thelper type 1 (Th1)/Th2 differentiation, and Th17 response after pancreaticoduodenectomy. Surgery (2010) 148(3):573-81. doi:10.1016/j.surg.2010.01.017

211. Marik PE, Flemmer M. Immunonutrition in the surgical patient. Minerva Anestesiol (2012) 78(3):336-42.

212. Furuhjelm C, Jenmalm MC, Falth-Magnusson K, Duchen K. Th1 and Th2 chemokines, vaccine-induced immunity, and allergic disease in infants after maternal omega-3 fatty acid supplementation during pregnancy and lactation. Pediatr Res (2011) 69(3):259-64. doi:10.1203/PDR.0b013e3182072229

213. Kong W, Yen JH, Ganea D. Docosahexaenoic acid prevents dendritic cell maturation, inhibits antigen-specific Th1/Th17 differentiation and suppresses experimental autoimmune encephalomyelitis. Brain Behav Immun (2011) 25(5):872-82. doi:10.1016/j.bbi.2010.09.012

214. Ye P, Li J, Wang S, Xie A, Sun W, Xia J. Eicosapentaenoic acid disrupts the balance between Tregs and IL-17+ T cells through PPARgamma nuclear receptor activation and protects cardiac allografts. J Surg Res (2011) 173(1):161-70. doi:10.1016/j.jss.2010.08.052

215. Weise C, Heunemann C, Loddenkemper C, Herz U, van Tol EA, Worm M. Dietary docosahexaenoic acid in combination with arachidonic acid ameliorates allergen-induced dermatitis in mice. Pediatr Allergy Immunol (2011) 22(5):497-504. doi:10.1111/j.1399-3038.2010.01133.x

Conflict of Interest Statement: The authors declare that the research was conducted in the absence of any commercial or financial relationships that could be construed as a potential conflict of interest.

Received: 19 December 2013; paper pending published: 08 January 2014; accepted: 11 February 2014; published online: 25 February 2014.

Citation: Nicolaou A, Mauro C, Urquhart P and Marelli-Berg F (2014) Polyunsaturated fatty acid-derived lipid mediators and T cell function. Front. Immunol. 5:75. doi: 10.3389/fimmu.2014.00075

This article was submitted to T Cell Biology, a section of the journal Frontiers in Immunology.

Copyright (C) 2014 Nicolaou, Mauro, Urquhart and Marelli-Berg. This is an openaccess article distributed under the terms of the Creative Commons Attribution License (CC BY). The use, distribution or reproduction in other forums is permitted, provided the original author(s) or licensor are credited and that the original publication in this journal is cited, in accordance with accepted academic practice. No use, distribution or reproduction is permitted which does not comply with these terms. 